Review

\title{
Green Building Rating Systems and the New Framework Level(s): A Critical Review of Sustainability Certification within Europe
}

\author{
Antonio Sánchez Cordero ${ }^{1}\left(\mathbb{D}\right.$, Sergio Gómez Melgar ${ }^{2, *(1)}$ and José Manuel Andújar Márquez ${ }^{2}$ \\ 1 Programa de Ciencia y Tecnología Industrial y Ambiental, Escuela Técnica Superior de Ingeniería, \\ Universidad de Huelva, CP. 21007 Huelva, Spain; antonio.sanchez443@alu.uhu.es \\ 2 TEP192 Control y Robótica, Escuela Técnica Superior de Ingeniería, Universidad de Huelva, \\ CP. 21007 Huelva, Spain; andujar@uhu.es \\ * Correspondence: sergomel@uhu.es
}

Received: 11 November 2019; Accepted: 18 December 2019; Published: 21 December 2019

\begin{abstract}
Increasing problems regarding pollution and climate change have long been demonstrated by scientific evidence. An important portion of carbon emissions are produced by the building sector. These emissions are directly related not only to the building's energy consumption, but also other building attributes affecting the construction and operation of existing buildings: materials selection, waste management, transportation, water consumption, and others. To help reduce these emissions, several green building rating system (GBRSs) have appeared during the last years. This has made it difficult for stakeholders to identify which GBRSs could be more suitable to a specific project. The heterogeneity of the GRBS scenario requires the creation of a transparent and robust indicator framework that can be used in any country within the European Union (EU), which is a common EU framework of core sustainability indicators for office and residential buildings Level(s) with the goal to provide a solid structure for building sustainability certification across all countries of the EU. This paper provides a comprehensive review of the most common GBRSs within the EU: Building Research Establishment Assessment Method (BREEAM), Deutsche Gesellschaft für Nachhaltiges Bauen (DGNB), Haute Qualité Environnementale (HQE), and Leadership in Energy \& Environmental Design (LEED), and a bottom up comparison of the influence in the final score produced by the indicators stated by Level(s). The indicators studied show a different influence of Level(s) indicators on every GBRS, where LEED and BREEAM were most affected while HQE and DGNB were less so. This paper demonstrates the heterogeneity of current GRBSs in the EU scenario and the difference between sustainability assessments, where DGNB seems to be more aligned to the current EU framework. Finally, the paper concludes with the need to work to achieve alignment between the GBRS and Level(s).
\end{abstract}

Keywords: Level(s); green building rating systems; Building Research Establishment Assessment Method (BREEAM); Deutsche Gesellschaft für Nachhaltiges Bauen (DGNB); Haute Qualité Environnementale (HQE); Leadership in Energy \& Environmental Design (LEED)

\section{Introduction}

The world's global energy consumption has been steadily increasing during the last several years, which has consequently produced an equivalent growth in atmospheric $\mathrm{CO}_{2}$ emissions [1]. The constant urbanization process of developing countries and worldwide development of the building construction sector have been defined as some of the most important causes of the growth in pollution [2]. At the same time, as the construction rate of cities and buildings keeps steadily growing, buildings in 
developed countries keep on increasing their energy demands to satisfy the inhabitant's needs [3,4]. It is a proven fact that human activity is the driven force of current climate change [5], and there is no time to lose to mitigate its impacts. Although some countries are making interesting efforts to improve energy performance, others are not [6,7], thus the only option to succeed seems to be a coordinated global effort. On 25 September, 2015, The 70th General Assembly of the United Nations approved the 2030 Agenda for Sustainable Development: Transforming our world (2030 Agenda) [8]. There, the committee established an action plan of 17 sustainable development goals (SDG) and 169 targets for planet and prosperity that must be followed by the signatory countries.

The EU had already been working along the same direction before signing the 2030 Agenda as it is included in its action plan [9], and measured by the United Nations Economic Commission for Europe (UNECE) [10]. Among the ten priorities defined by the EU to converge with the 2030 Agenda, the first one of them, A new Boost for jobs, growth and investment, is based on the principle of circular economy, which is included in the EU 2015 Circular Economy Action Plan [11] and confirmed in the EU 2017 Work Programme [9]. It contains the adoption of several SDGs: SDG6, SDG8, SDG9, SDG11, SDG12, SDG13, SDG14, and SDG15. However, how these SDG can be achieved and how can they be measured, evaluated, and compared requires the introduction of specific tools and frameworks.

In 2014, the European Commission (EC) released the Communication on Resource Efficiency Opportunities in the Building Sector-COM (2014) 445 [12], which declared the need for a common European approach to improve the environmental performance of buildings throughout their whole lifecycle. In fact, this is a policy maker response with the objective to organize the complex GBRS ecosystems worldwide and specifically within the EU. According to different authors, there are between 70 [13] and 600 [14] GBRSs working at the moment.

In the construction environment where buildings trends are to gradually reduce its energy consumption to become minimum energy buildings (MEB) [15], different areas of building design, construction, and operation like materials selection [16] or waste management $[17,18]$ are producing a proportionally higher impact, which introduces the need to provide comprehensive tools that go beyond energy benchmarking.

As Doan et al. [19] defines, GBRSs are focused on the measurement of environmental aspects like energy, land, water, and materials. These provide more affordable and realistic measurements for the industry than others called sustainable building rating systems, justifying a discussion to replace the word green for sustainability [20]. Although it is not yet widely accepted and these two words are still far from convergence, it reveals terms that must be used carefully due to its transcendence. Today, there is not a single accepted definition about what is sustainability and what aspects it includes, but it is commonly accepted that it contains no less than three aspects that are environmental (ENV), economic (ECO), and social (SOC), as stated by Brundtland in 1987 [21]. From there, other pillars were included: a fourth pillar called institutional (INS), which is not usually commented [22], and later, in 2010, The United Cities and Local Government (UCLG) enounced the fifth pillar: culture [23]. Therefore, there is uncertainty about what concepts will include sustainability in the future, but it is still the environmental impact that weighs more in current GBRSs [14,24-27]. Due to the uncertain definition of what we refer to with regard to sustainability, the term green will prevail for the moment.

In 1990, the first version of The Building Research Environmental Assessment Method (BREEAM) [28] was launched in the United Kingdom. This was considered the first GBRS published in the world [13]. From then, many others like the Leadership in Energy and Environmental Design (LEED) [29], Deutsche Gesellschaft für Nachhaltigies Bauen (DGNB) [30], and Haute Qualité Environnementale (HQE) [31] have followed with similar purpose: to provide reliable assessment for buildings through an indicator system with several different criteria. Now, most have spread wide from the underground to mainstream, and figures of building's certified worldwide have exponentially increased from just a few at the end of the 20th century to dozens of thousands today [32].

Among them, LEED and BREEAM are described as the most popular, although DGNB and HQE have a certain degree of international success. The Comprehensive Assessment System for 
Built Environment Efficiency (CASBEE) [33], and GREEN STAR [34], which are not used within the EU, also have international versions and are widely used in other regions outside the EU [13]. The Environmental Standard for Green Buildings (ESGB) [35], which is released and controlled by the Ministry of Urban Housing and Rural Development of the People's Republic of China (MOUHURD), has no international version, but due the size of China, it is obviously used by many stakeholders [36]. Apart from BREEAM, DGNB, HQE, and LEED, many countries in the EU have developed their own GBRSs [13] based on four different strategies (see Table 1 and Figure 1):

- A local adaptation of BREEAM INT GBRS made by national institutes [37] like BREEAM ES [38], BREEAM NL [39], BREEAM DE [40], BREEAM NOR [41], and BREEAM SW [42].

- A local adaptation of an SBTool, made by a national member of The World Green Building Council (WGBC, London, UK) such as SBToolCZ [43], SBToolPT [25,44], Instituto per l'innovazione e trasparenza degli appalti e lacompatibilita ambientale (ITACA) [14,45,46], VERDE [47,48], and the Total quality building assessment (TQB) [49].

- A new GBRS developed by a national member of the WGBC like DGNB, HQE, Miljoyggnad, and Minergie ECO [50].

- Independent attempts to create a holistic transparent and regionally adaptable GBRS like Open House [51], which can be seen as the first step of LEVEL(s).

Table 1. List of the most representative GBRS within the EU.

\begin{tabular}{|c|c|c|c|c|c|}
\hline Country & GBRS Name & Organization & Starting & Version & References \\
\hline \multirow{2}{*}{ Austria } & TQB 2010 & OGNB & 2010 & National & [52] \\
\hline & BREEAM AT & DIFNI & & National & {$[37,53]$} \\
\hline Czech Republic & SBToolCZ & IISBE Czech/CIDEAS & 2010 & National & [43] \\
\hline France & HQE & HQE & 1997 & International & [31] \\
\hline \multirow[t]{2}{*}{ Germany } & DGNB & $\begin{array}{l}\text { German Sustainable } \\
\text { Building Council }\end{array}$ & 2008 & International & [54] \\
\hline & BREEAM DE & TÜV SÜD DIFNI & 2011 & National & {$[37,40]$} \\
\hline \multirow{2}{*}{ Italy } & LEED Italia & Italy GBC & 2006 & National & [55] \\
\hline & ITACA & IISBE Italia & 2004 & National & [45] \\
\hline The Netherlands & BREEAM NL & Dutch GBC & 2011 & National & [37] \\
\hline Norway & BREEAM NW & Norwegian GBC & 2011 & National & [37] \\
\hline Portugal & SBToolPT & iiSBE PT & 2009 & National & {$[25,44]$} \\
\hline \multirow{2}{*}{ Spain } & VERDE & Spanish GBC & 2011 & National & [48] \\
\hline & BREEAM ES & ITG & 2010 & National & [37] \\
\hline \multirow{2}{*}{ Sweden } & BREEAM SE & \multirow{2}{*}{ Swedish GBC } & 2011 & National & [37] \\
\hline & Miljöbyggnad & & 2011 & National & [56] \\
\hline \multirow{2}{*}{ Switzerland } & BREEAM CH & DIFNI & 2011 & National & [37] \\
\hline & Minergie ECO & MINERGIE & 1998 & National & [50] \\
\hline \multirow{3}{*}{ United Kingdom } & BREEAM & \multirow{3}{*}{ BRE } & 1990 & International & [37] \\
\hline & HQM & & 2015 & National & [57] \\
\hline & CEEQUAL & & 2011 & International & [58] \\
\hline
\end{tabular}

The whole picture represents a total of more than 37 international and $54 \mathrm{EU}$ certificates with more than 500 different indicators $[51,59]$ working in the EU at the same time, which creates a heterogeneous system that is difficult to manage for policy makers and stakeholders. Therefore, this scenario requires the creation of a transparent and robust framework of indicators that can be used by policy makers and stakeholders in any country within the EU. As a consequence, in August 2017, Level(s), a voluntary 
reporting framework to improve the sustainability of buildings within the EU, was launched [60] and its full development process can be followed through the website of the Joint Research Centre (JRC) [61]. The framework is still in its beta version, and has been tested by 136 projects in 21 different countries applied to buildings from different typologies such as residential and others, but the JRC has already established spring 2020 as the official end of the testing period, and the date for the launch of the final version [62].

The Level(s) indicators proposed are organized in six different categories: emissions, resources, water, wellbeing and comfort, resilience, and adaptation to climate change [61]. This categorization serves as a basis for a comparison between the most popular GBRSs in the EU. This paper provides a comprehensive top-down critical review between most used GBRSs in the EU and Level(s) to identify potentially emerging conflicts in the application of the new framework. Furthermore, the specific objectives were to:

- Establish a comparison between the most widely used GBRSs in the EU: BREEAM, DGNB, HQE, LEED, and describe the main differences according to regional adaptation and the indicators included as well as stages covered.

- Provide a comparison between those indicators stated by Level(s) and similar ones included in BREEAM, DGNB, HQE, and LEED.

- Identify similarities and conflicts between Level(s) and current GBRSs in EU to find areas that may be considered in both future versions of the framework, and the mentioned GBRS.
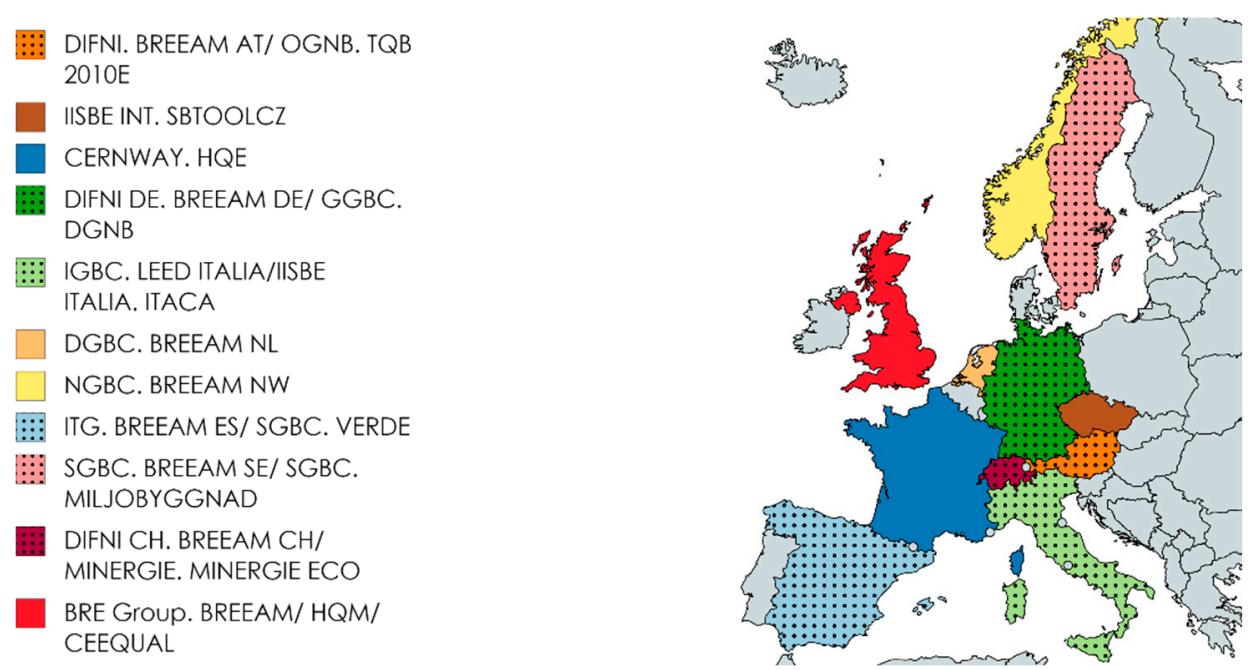

Figure 1. Map of most representative GBRS within the EU.

\section{Methodology}

\subsection{Materials and Methods}

Due to the nature of this research, which is mainly a critical revision paper, software tools were the only material used. No other materials like hardware devices, surveys, or others were used. These software tools will be explained in detail in the following section.

In summary, this research used a 5-step methodology to provide a comprehensive review of the current status of GBRS within the EU (Figure 2).

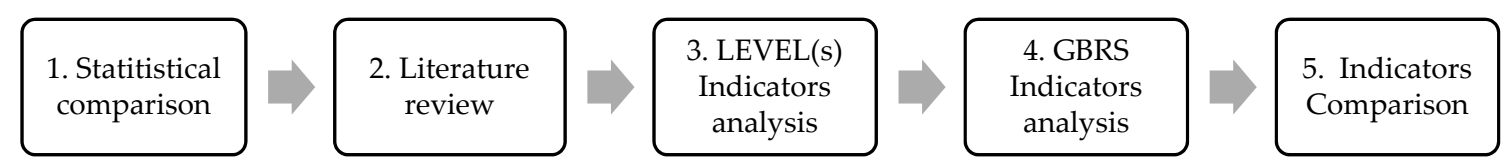

Figure 2. The 5-step methodology flux diagram. 
The indicator system is the core of the sustainability assessment process. This research was conducted in a double way: a bibliographic review from up-down to determine the most interesting topics in the current research as well as a bottom-up technical manuals review focused on indicator systems as described in the following sections.

\subsection{GBRS Statistical Comparison}

According to the objective of this research paper, a ranking of the most used GBRSs within the EU must be defined to proceed with a consistent methodology that can be applied for every GBRS carried out in any of the EU members. Therefore, the establishment of the aforementioned ranking was defined as the first step of this methodology. As can be seen in Figure 3, the statistical comparison carried out includes both registered and certified GBRSs.
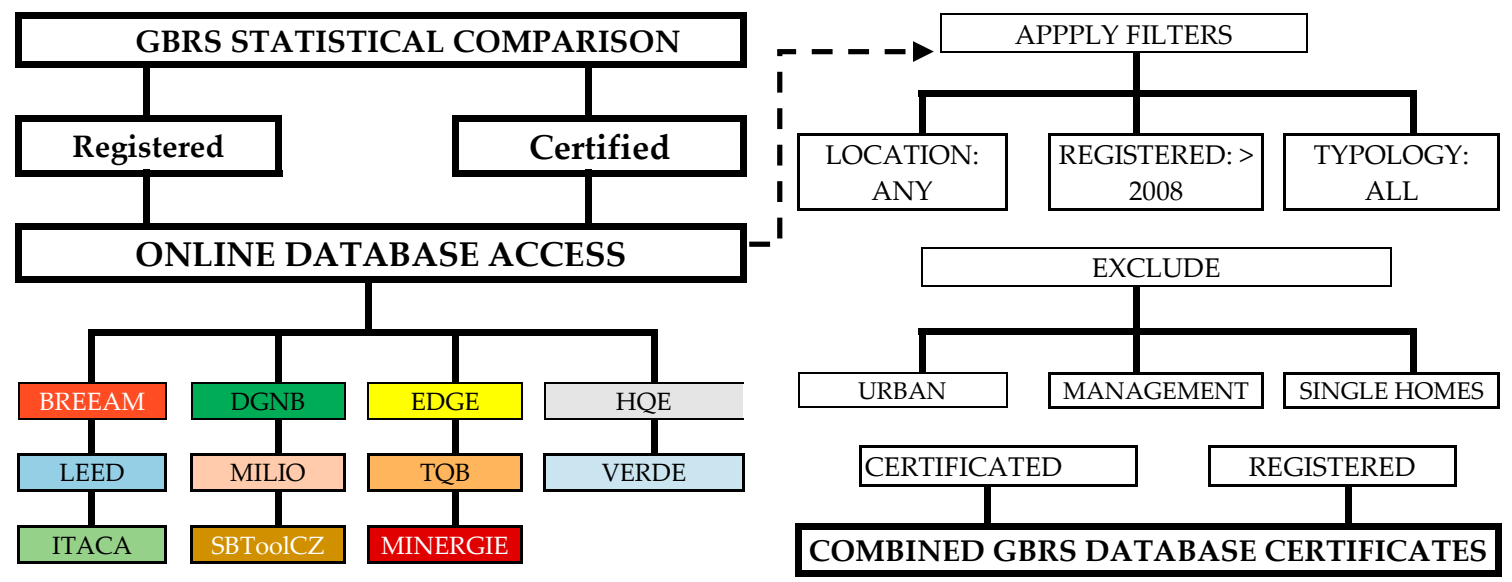

Figure 3. GBRS methodology for statistical comparison.

To obtain reliable data on the number of certificates from the most representative GBRSs in the EU, this research gathered data from official websites like BREEAM [37], DGNB [54], HQE [63], LEED [64], MILJOYGGNAD [56], MINERGIE [50], and TQB-2010 [52]. For those with no available data on their websites, it was necessary to proceed with a consultation process [64-68], carried out on 31 July, 2019. EDGE [69] and VERDE [48] responded with a detailed list of certified and registered buildings as requested. Some others neither published detailed data on the website nor sent requested information, like ITACA and SBToolCZ. Fortunately, there were only a few of them and most likely those with a smaller number of certificates across the whole EU. Future updates of this work will probably include more comprehensive data about these minoritarian GBRSs.

According to the objective of this research, and to provide consistent requirements with Section 2.2 that can be easily compared, some exclusions were applied: data before 2008, single homes, urban developments, and building management certification (Figure 3).

\subsection{GBRS Literature Review}

Once the major worldwide GBRSs were defined, a literature review research was conducted. The aim of this second step was to (a) observe the development of research in green rating systems; (b) find out how popular they are in the research community; (c) discover through previous scientific papers which methodologies can be used to compare GBRS; and (d) identify which GBRSs still received less attention from researchers, even when they had an strong market presence.

Scopus (SCO) and Web of Science (WOS) were selected as the research databases, according to their relevance in the scientific field [70]. According to the objective of this paper and the results from Section 3.1, the following acronyms were defined as keywords: BREEAM, DGNB, HQE, LEED and Levels in the main search fields as the title, abstract, and keywords. Later, some filters were applied to narrow the results given by search: only journal articles, published after 2008, in the English language. 
Finally, an author's personal revision was applied to discard inadequate results that may arise when using the LEED acronym because of its ambiguous significance in other disciplines. The results from both SCO and WOS were finally merged into a single database managed with Mendeley software (Figure 4).
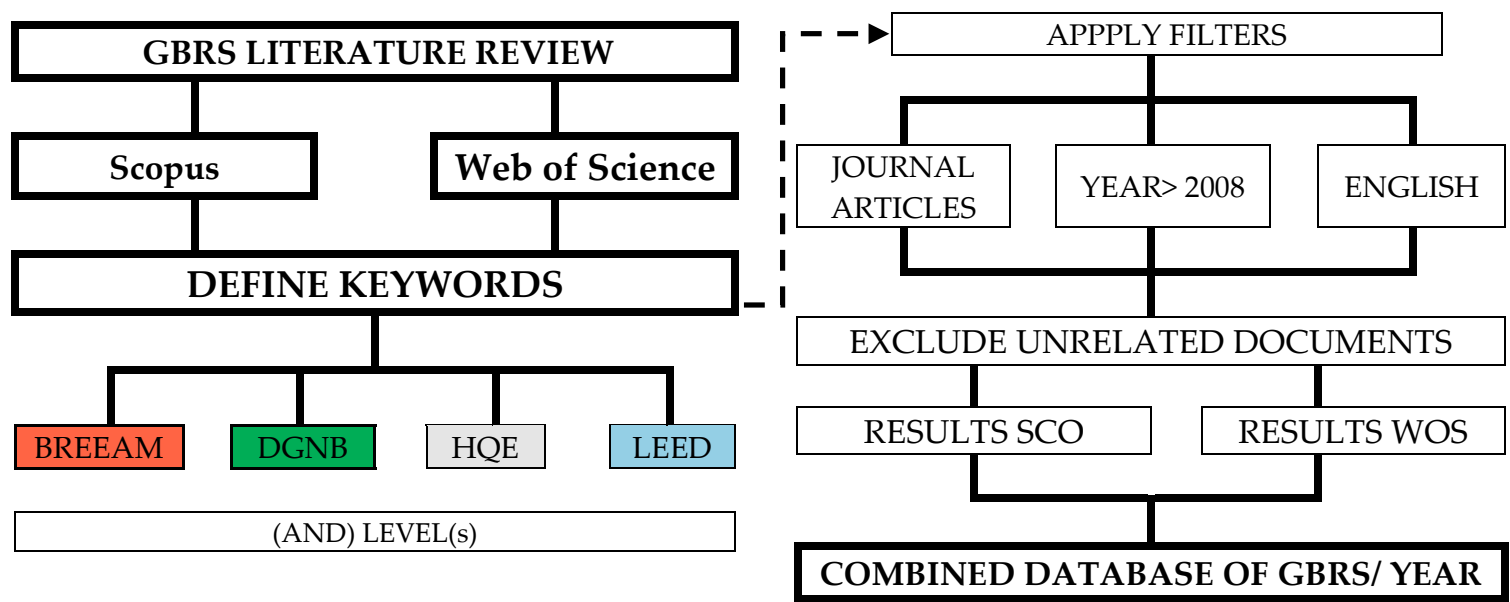

Figure 4. GBRS methodology for the literature review.

\subsection{Indicator Analysis}

Most common GBRSs like BREEAM, DGNB, HQE, and LEED are based on an hierarchical structure with a top-down organization as follows: categories systems (CAS), Issue System (ISS), Criteria System (CRS), and Indicators system (IDS) [71]. Terms like CAS, CRE, CRS, and IDS are commonly used by different technical manuals and authors [36]. BREEAM terms for structure classification were adopted in this paper [28], as can be seen in Table 2. CAS is defined as a Macro-objective in Level(s), Topic in DGNB, and Theme in HQE. ISS is called the target in HQE [72], requirement in LEED [73], and criteria group in DGNB [30]. Finally, CRS is called the core indicator in Level(s), Criteria in DGNB, Sub-Target in HQE, and Requirements in LEED. From all of these items, the user operation item (UOI) defines the element that must be addressed to obtain the score. This concept is relevant to the methodology because it shows the difficulties in accurately comparing scoring systems of different GBRSs.

Table 2. Summary of elements included in the methodology and user operation item.

\begin{tabular}{ccccc}
\hline GBRS & Category (CAS) & Issue (ISS) & Criteria (CRS) & Indicator (IDS) \\
\hline Level(s) & Macro-objective & & Core indicator & Indicator ${ }^{1}$ \\
BREEAM & Category & Issue & Criteria ${ }^{1}$ & Indicator \\
DGNB & Topic & Criteria group & Criteria & Indicator ${ }^{1}$ \\
HQE & Theme & Target & Sub-target & Indicator ${ }^{1}$ \\
LEED & Category & Credit & Requirements ${ }^{1}$ & Indicator \\
\hline \multicolumn{5}{c}{${ }^{1}$ User operation item (UOI). }
\end{tabular}

Most of the common GBRS scoring methods are summarized in Figure 5, where the structure follows BREEAM and LEED details in terms of the UOI. According to a bottom-up scoring system, points obtained by criteria accomplishment provide each category score. In BREEAM, the score is weighted by a different coefficient per category while in LEED the coefficient is 1 . The DGNB and HQE scoring system is similar to BREEAM and LEED, however their UOI is an indicator. Later, a cumulative scoring process was carried out to obtain the global mark that these IDS would produce in theory.

Due to the geographical scope of this research, only the international version of technical manuals for BREEAM, DGNB, HQE, and LEED were considered (see Table 2).

According to the heterogeneity of different methods, this research suggests an open methodological approach (see Table 3) where each GBRS version listed in Table 3 is presented to determinate the 
comparison framework. Second, the same GBRS versions were separated into CAS, ISS, and IDS or CRS, at each depth system of that presented in Figure 5. Finally, a comparison matrix between the indicators covered by Level(s) and BREEAM, DGNB, HQE, and LEED are presented.

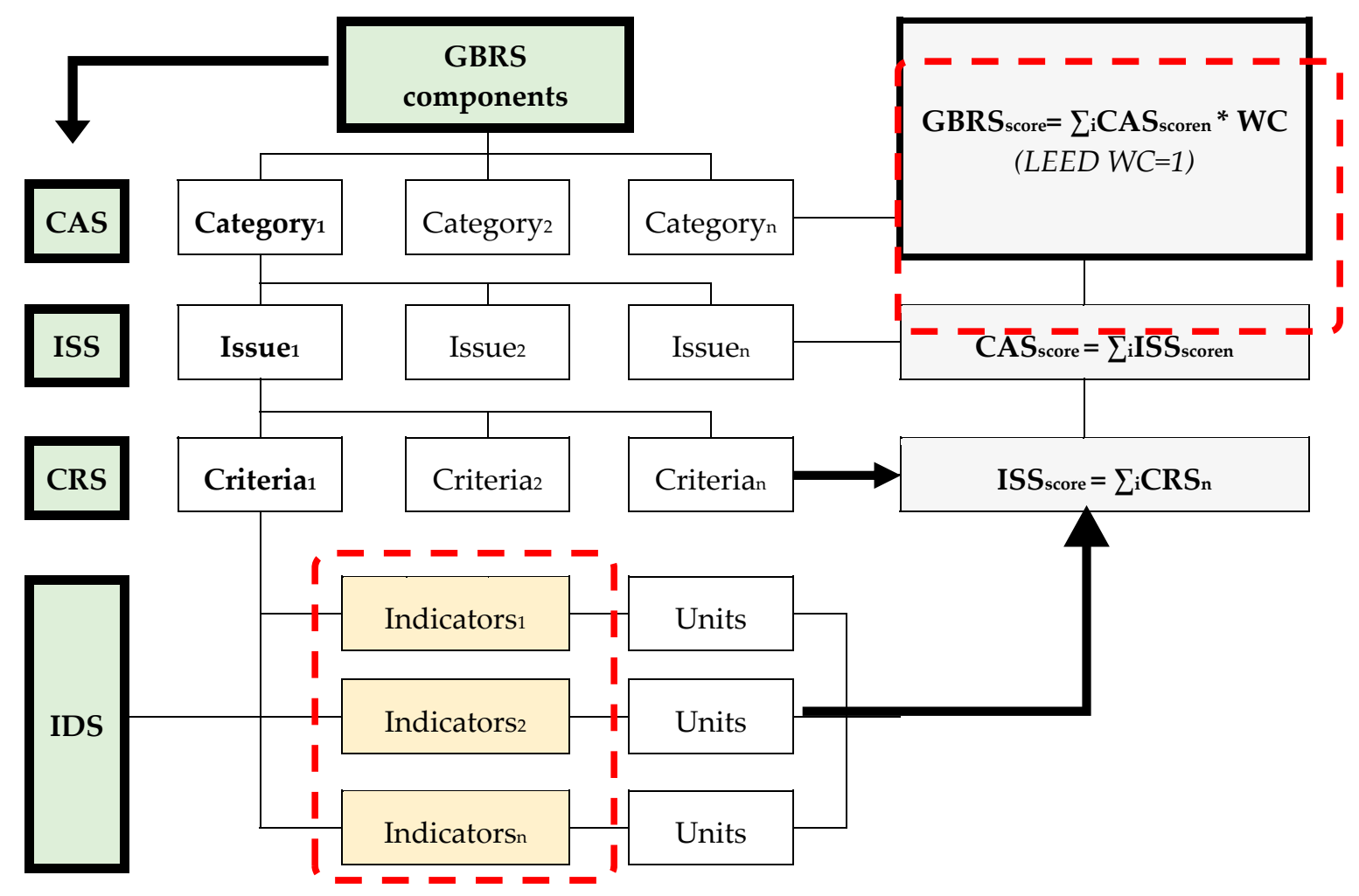

Figure 5. GBRS scoring process overview (not applicable to DGNB and HQE).

Table 3. Selected manuals of Level(s), BREEAM, DGNB, HQE and LEED.

\begin{tabular}{cccc}
\hline GBRS & Version & Published & References \\
\hline Level(s) & v1.0 & 2017 & {$[74,75]$} \\
BREEAM & INT NC SD233 v2.0 & 2016 & {$[28]$} \\
DGNB & INT 2014 & 2014 & {$[76]$} \\
HQE & v1.01 & 2016 & {$[72]$} \\
LEED & BD + C v4.1 & 2019 & {$[73]$} \\
\hline
\end{tabular}

New construction and restoration of residential and office buildings.

\section{Results}

\subsection{Most Used GBRS within the EU}

According to the methodology explained in Figure 3, consultations and web searches provided a comprehensive spreadsheet that was transformed into Figures 6 and 7. Figure 6 includes a comparison between registered buildings $(9145)$ and those that finally obtained certification $(11,365)$. On the right side, Figure 7 includes a GBRS certification breakdown including the most widely used GBRSs within the EU: BREEAM (65.00\%), HQE (13.58\%), DGNB (6.49\%), LEED (5.46\%), Miljobyggnad (4.02\%), EDGE $(3.61 \%)$, TQB $(1.52 \%)$, and VERDE $(0.35 \%)$. These results form the basis that support the GBRS selected for this research. 


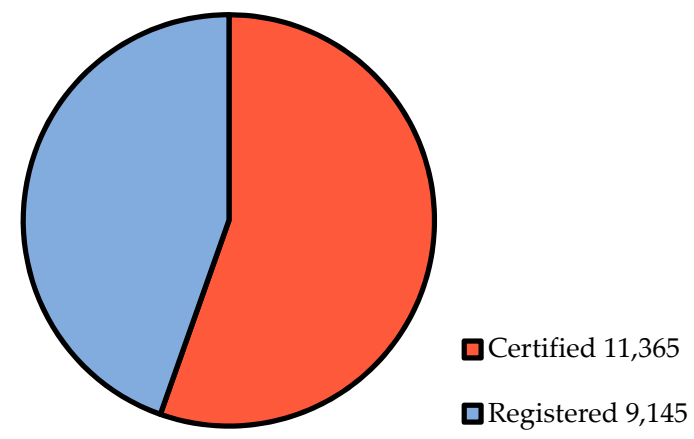

Figure 6. Registered vs. certified GBRS in the EU.

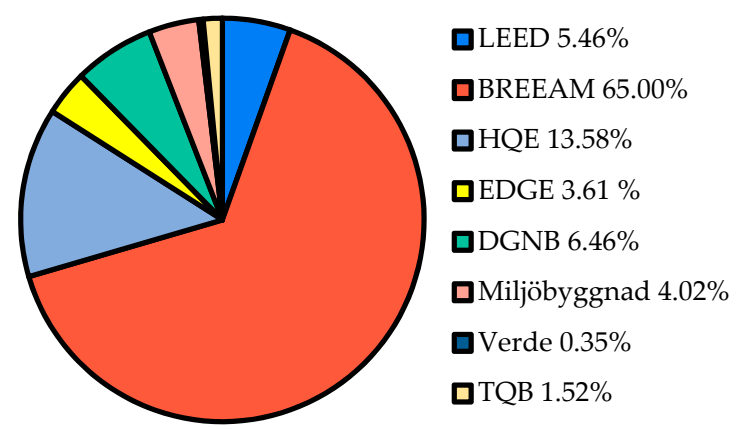

Figure 7. GBRS distribution in Europe.

\subsection{GBRS Literature Review}

A total of 1169 papers were obtained from the scientific search made via SCO and WOS through the methodology proposed in Figure 3. These results were combined into a spreadsheet to create two working databases:

1. A comprehensive database with whole number of papers per GBRS and year, which was used to produce Figures 8 and 9. In Figure 8, the coloured lines show the total amount of research papers by GBRS/year as well as a cumulative of the four together bar per year. This gives an idea of both the full number of GBRS research papers, but also the proportion of each GBRS studied. Figure 9 shows the number of papers/years, which combined two, three, or four of the GBRSs included.

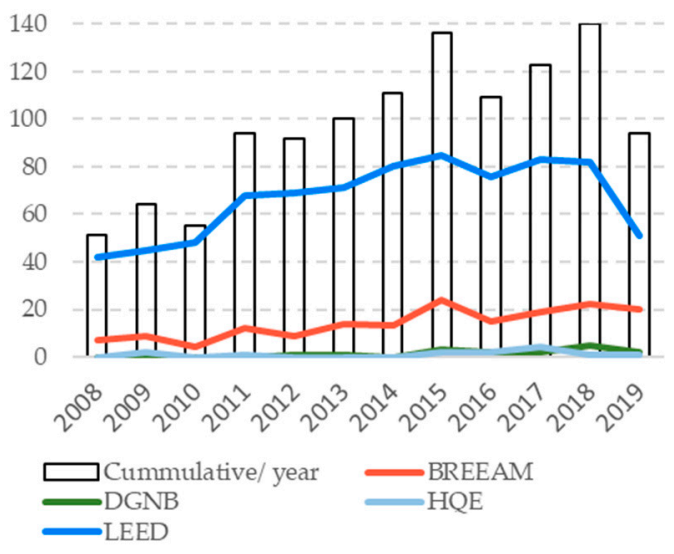

Figure 8. GBRS papers in SCO and WOS. 


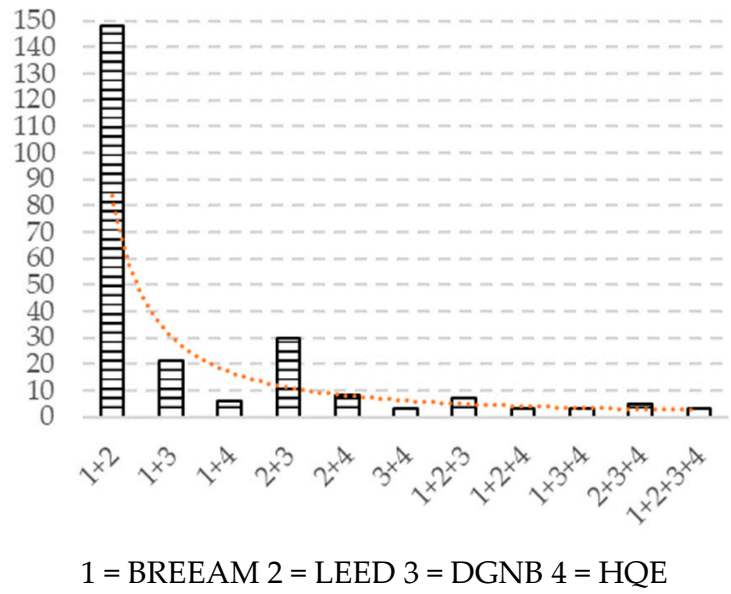

Figure 9. GBRS papers in SCO and WOS.

2. A reduced database including only papers published in the second quartile (Q1 and Q2) $[77,78]$. with six or more papers published on GBRSs from 2008 to 2019. These were used to produce Figure 10, where the coloured line chart shows the GBRS published per journal each year. Included journals were: Architectural Design, Building Research and Information, Facilities, Journal of Cleaner production, Sustainable Cities and Society, Building and Environment, Energy and Buildings, International Journal of Sustainable Building Technology and Urban Development, Sustainability, and Journal of Management in Engineering.
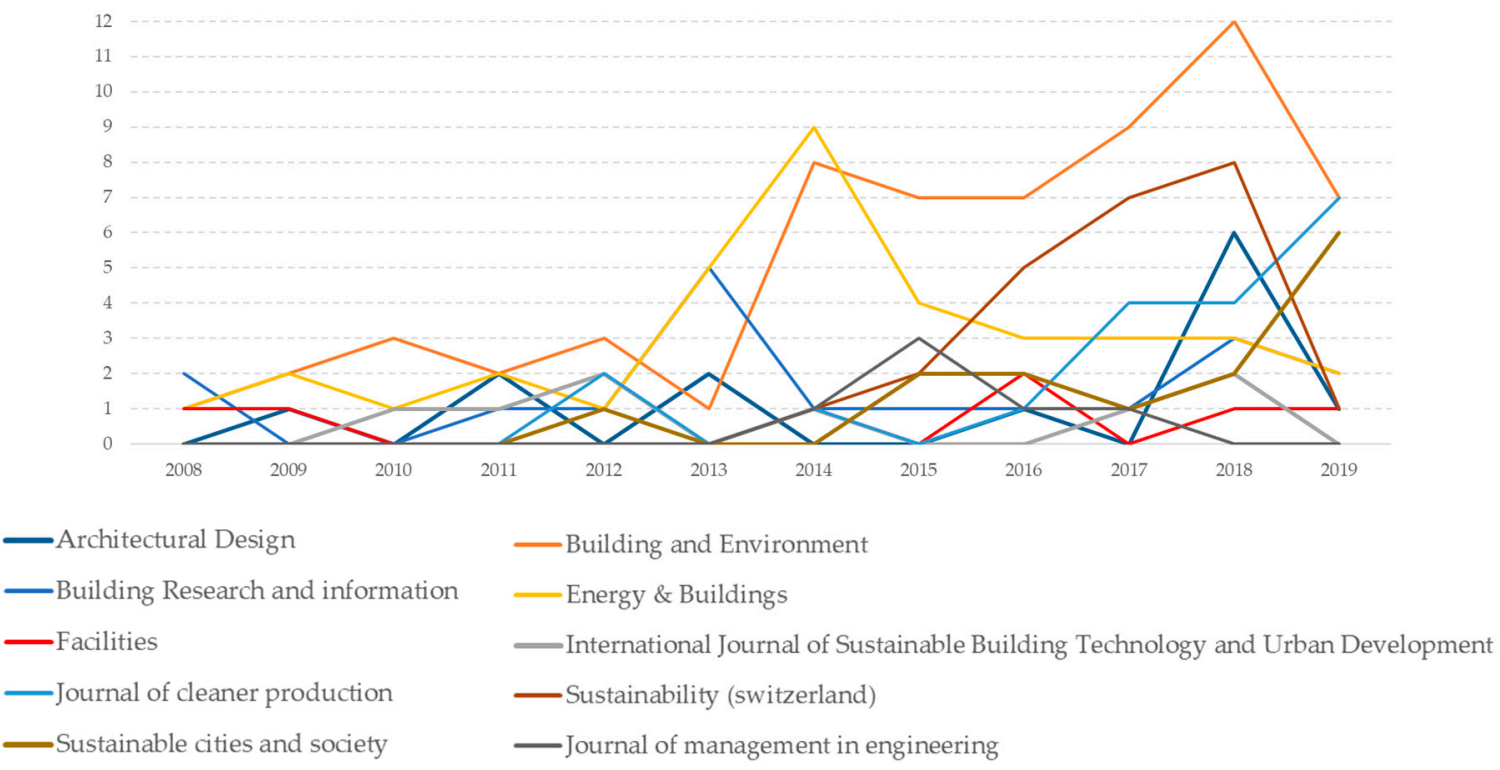

Figure 10. Evolution of published papers in the Q1 and Q2 journals.

Data from Figure 10 have been presented in Table 4, where more relevant journals according to its quartile classification [78] have been organized by study areas: Architecture; Building and construction; Renewable energy, sustainability and the environment, and Engineering [77].

Most relevant papers within the database obtained from the literature review can be classified into three groups (see Figure 11), according to their research objective: those providing New Tools (NT), Frameworks, or Regional Adaptation (RA) of current GBRS, see Appendix A, Table A1; those providing a comparison between different GBRSs (GBRSC), see Appendix A, Table A2; and finally, other papers that cannot be included in any of the preceding categories. 
Papers from all regions were analysed to determine the kinds of comparisons that authors have conducted. As mentioned in Figure 11, the GBRS score was structured into the CAS, ISS, and IDS. Therefore, Figure 12 presents the proportion of papers focused on these systems. There, it can be seen that few authors provided a category system comparison, while the research objective for most authors was focused on CRS or IDS.

Table 4. Number of papers on the selected journals.

\begin{tabular}{ccccc}
\hline Areas & Journal & H Index & Quartile & Papers \\
\hline Architecture & Architectural design & 19 & 2 & 13 \\
\hline & Building and environment & 124 & 1 & 62 \\
Building and & Building research and information & 72 & 1 & 18 \\
Construction & Energy and buildings & 147 & 1 & 36 \\
& Facilities & 38 & 2 & 7 \\
& International journal of sustainable building technology and & 11 & 2 & 8 \\
\hline Renewable energy, & urban development & 150 & 1 & 19 \\
sustainability and & Journal of cleaner production & 53 & 2 & 24 \\
environment & Sustainability & 34 & 2 & 14 \\
\hline Engineering & Sustainable cities and society & 55 & 1 & 61 \\
\hline
\end{tabular}

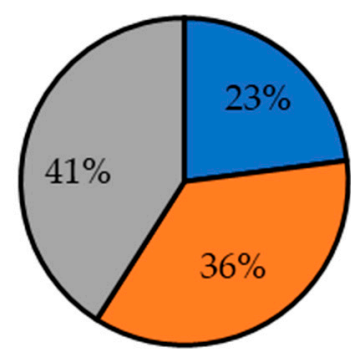

\section{口NT or RA $\square$ GBRSC $\mathbf{a}$ Others}

Figure 11. GBRS relevant papers between 2008 and 2019 classified by main objective.
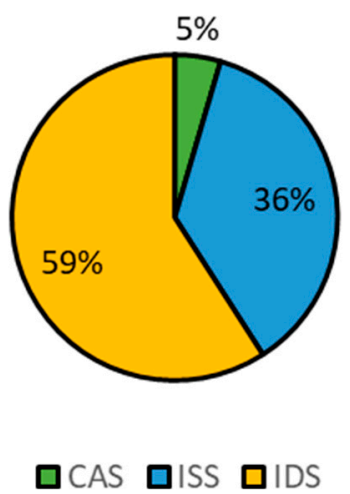

Figure 12. GBRS relevant papers between 2008 and 2019 classified by depth of comparison.

According to the geographical context of this research, which is the EU, selected research papers were classified by areas included into the study, as seen in Figure 13. GBRSs are highly affected by local conditions, and this is a matter of importance for many authors who work with the aim to provide improvements based on regional adaptations. Asia shows the highest figure, while North America (NA) had the lowest, with the EU and the Middle East and North Africa (MENA) in the middle. 
Looking at the whole picture, 33 out of 46 papers provided a geographical contextualization while 13 out of 46 did not. Therefore, the majority of authors published papers focused on a region.

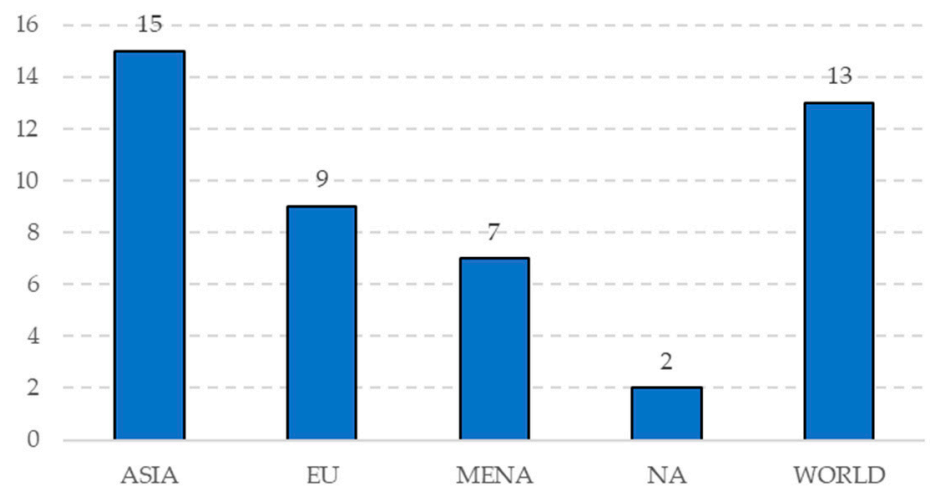

Figure 13. GBRS relevant papers between 2008 and 2019 classified by region of study.

\section{3. $\operatorname{Level}(s)$}

Level(s) is a voluntary tool developed by the Joint Research Centre of the EU. Although it is still in a beta version, its official release is expected by spring 2020 [60], with the aim to provide transparency and robustness to European sustainability policies. Instead of describing a set of mandatory requirements, Level(s) is based on the concept of Levels of deepness from beginners to experts. These are Level (1), Level (2), and Level (3). Level (1) is a common assessment, Level (2) is a comparative assessment, and finally Level (3) is an optimization assessment. This approach is based on a progressive accuracy increase of the tools involved, which allows all kinds of stakeholders, from less educated to experts, to work within the same framework.

The framework is organized into six categories, called macro-objectives, and 14 indicators (see Table 5), which are defined as the UOI. It also provides a set of Life Cycle (LC) tools and a value risk rating. Level(s) can be used directly or via another GBRS aligned with the G17 Alliance [79]. As a framework, the Level(s) score will vary depending on regional conditions. Level(s) is based on a performing situation where 136 case studies were selected to provide results with the aim to refine the indicators. Later, national governments are expected to set values and limits to core indicators that can be finally transformed into a final score. Some EU GBRS, like the latest version of DGNB have already included specific sections to provide interaction with Level(s). It is expected that there will be a progressive adaptation by the other GBRSs developed in the EU to this framework, or at least GBRSs depending on the members of the G17 Alliance.

\subsection{GBRS Manuals Revision}

\subsubsection{BREEAM}

BREEAM, which was first launched in 1990 in the UK by The Building Research Establishment (BRE) [80], released its international version in 2008. Since then, 7387 buildings have been certified with BREEAM, from the whole data of 13,824 registered buildings. Data were obtained until July 2019 according to the methodology depicted in Figure 3. The scoring system was based on a bottom-up methodology as described in Figure 5 including nine CAS, 52 ISS, 76 CRS, and their corresponding IDS as UOI. Each criterion group provides a certain number of points that makes the sum per category. Later, a percentage-weighting factor was assigned to each category to obtain the final score. According to the number of points, the awarded buildings can be rated as: unclassified ( $<30$ points), pass ( $\geq 30$ points), good ( $\geq 45$ points), very good ( $\geq 55$ points), excellent ( $\geq 70$ points), and outstanding ( $\geq 85$ points).

CAS are management (MAN), health and wellbeing (HEA), energy (ENE), transport (TRA), water (WT), materials (MAT), waste (WAS), land use and ecology (USE), pollution (POL), and innovation (INV). 
BREEAM, which was originally applied in the UK, incorporates several measures to enhance local adaptation to different countries. First, BREEAM is the only GBRS to include a local assessor, who acts as both a consultant and an on-site auditor. Second, it is organized in categories, which are weighted according to site conditions [78]. Finally, in locations where the volume of certified buildings is high, BRE boosts cooperation with local institutes to adapt BREEAM INT to local conditions, language, and regulations.

The scoring system has a maximum score of 100 points, plus there are up to 10 additional points for an extra category, which includes innovation criteria.

Table 5. Summary of CAS, CRS and IDS in Level(s).

\begin{tabular}{|c|c|c|c|c|c|c|}
\hline CAS & $\begin{array}{l}\text { Greenhouse Gas } \\
\text { Emissions along a } \\
\text { Building's Life } \\
\text { Cycle (LC) }\end{array}$ & $\begin{array}{c}\text { Resource Efficient and } \\
\text { Circular Material LC }\end{array}$ & $\begin{array}{l}\text { Efficient Use } \\
\text { of Water } \\
\text { Resources }\end{array}$ & $\begin{array}{l}\text { Healthy and } \\
\text { Comfortable } \\
\text { Spaces }\end{array}$ & $\begin{array}{c}\text { Adaptation and } \\
\text { Resilience to Climate } \\
\text { Change }\end{array}$ & $\begin{array}{l}\text { Optimised } \\
\text { LC Cost and } \\
\text { Value }\end{array}$ \\
\hline CRS 1 & $\begin{array}{l}\text { Use stage energy } \\
\text { performance }\end{array}$ & $\begin{array}{l}\text { LC tool: Building bill of } \\
\text { materials }\end{array}$ & $\begin{array}{l}\text { Total water } \\
\text { consumption }\end{array}$ & $\begin{array}{l}\text { Indoor air } \\
\text { quality }\end{array}$ & $\begin{array}{l}\text { LC tools: scenarios for } \\
\text { projected future } \\
\text { climatic conditions }\end{array}$ & LC costs \\
\hline CRS 1.1 & $\begin{array}{c}\text { Primary energy } \\
\text { demand }\end{array}$ & & & & & \\
\hline CRS 1.2 & $\begin{array}{c}\text { Delivered energy } \\
\text { demand }\end{array}$ & & & & & \\
\hline CRS 2 & $\begin{array}{l}\text { LC warming } \\
\text { potential }\end{array}$ & $\begin{array}{l}\text { LC tools: scenarios for } \\
\text { building lifespan, } \\
\text { adaptability and } \\
\text { deconstruction }\end{array}$ & & $\begin{array}{l}\text { Time outside } \\
\text { of thermal } \\
\text { comfort } \\
\text { range }\end{array}$ & & $\begin{array}{l}\text { Value } \\
\text { creation and } \\
\text { risk factors }\end{array}$ \\
\hline CRS 3 & & $\begin{array}{c}\text { Construction and demolition } \\
\text { waste and materials }\end{array}$ & & & & \\
\hline CRS 4 & & $\begin{array}{c}\text { Overarching assessment tool: } \\
\text { Cradle to grave LC } \\
\text { Assessment }\end{array}$ & & & & \\
\hline
\end{tabular}

\subsubsection{DGNB}

DGNB was launched in 2009 by the Deutsche Gesellschaft für Nachhaltiges Bauen (DGNB). In 2014, an international version was released [13], but its latest versions was only just released in November 2019, coinciding with the writing of this paper. According to data obtained through the methodology explained in Figure 3, in July 2019, it showed 924 registered buildings including 734 already certified buildings, which ranks it in fourth position of the GBRS in terms of the number of certified buildings. The DGNB system includes three equally weighted categories regarding three of the most commonly accepted sustainability pillars [13,14,19,81], which are environmental, economic, sociocultural, and functional quality (see Figure 14). The DGNB system includes three other categories with less importance as the weighting factors: technical, process, and site quality. Furthermore, 10 ISS and 38 CRS with corresponding IDS are included. IDS acts as the UOI in the DGNB. The final score depends on the weighting methodology as stated in Figure 5. Weighting of these criteria is different according to the building typology.

The maximum score is $100 \%$, and certification can be rated as: DGNB Bronze ( $\geq 35$ points), DGNB Silver ( $\geq 50$ points), DGNB Gold ( $\geq 65$ points), and DGNB Platinum ( $\geq 80$ points). 


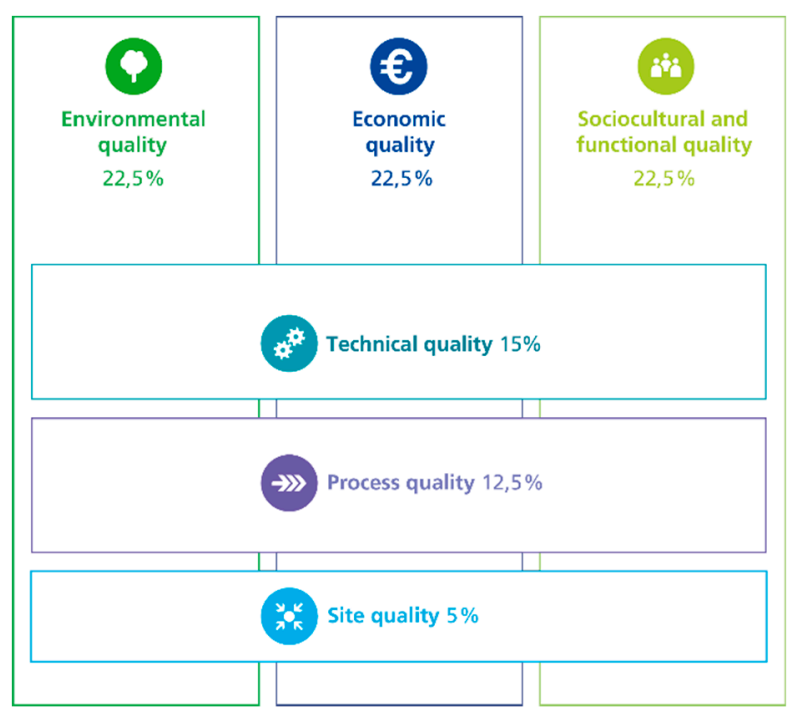

Figure 14. Weighting factors of the DGNB categories from the DGNB 2020 international version.

\subsubsection{HQE}

HQE was launched in 1994 in France with the aim of guaranteeing the high environmental quality of buildings. Since 2013, the HQE international version has been available and CERWAY is the organization in charge of supporting worldwide [72]. In July 2019, there were 1543 certified buildings from a total number of 2139, according to the methodology in Figure 3. The scoring system is based on four themes, 14 CAS, 37 ISS, 53 CRS, and IDS (>53). In HQE, indicators act as UOI and each category has the same importance so there are no weighting coefficients. The target provides points to each category that can achieve three performing Levels: prerequisite, performing, and high performing. To finally become certified, a building must achieve the high performing Level in at least three categories and the basic Level in a maximum of seven categories.

The CAS considered are site, components, worksite, energy, water, waste, maintenance, hygrothermal comfort, acoustic comfort, visual comfort, spaces quality, air quality, and water quality.

\subsubsection{LEED}

LEED was first launched in 1998 in the USA by The US Green Building Council (USGBC). Although it is one of the most popular GBRSs in the world, its figures in the EU are significantly smaller than other European GBRSs. In July 2019, it showed 1973 registered buildings including 621 already certified buildings. Data were obtained through the methodology explained in Figure 3.

The scoring system is based on a bottom-up methodology like that described in Figure 5, but there are no weighting factors, therefore, the final score is directly obtained by simple criterion addition (see Figure 15). In LEED, these criterion act as UOI.
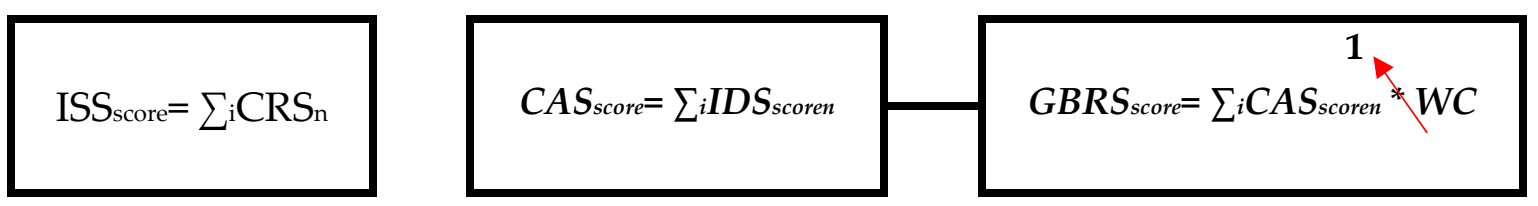

Figure 15. The LEED scoring system that does not include a weighting factor.

The LEED scoring system includes seven CAS, 62 ISS with 16 of them defined as prerequisite (not valid for scoring), and CRS (76) and IDS (>76) [73]. According to the number of points awarded, buildings can be rated as: Unclassified ( $<40$ points), Certified ( $\geq 40$ points), Silver ( $\geq 50$ points), Gold ( $\geq 60$ points), and Platinum ( $\geq 80$ points). 
The CAS are location and transportation (LT), sustainable sites (SS), water efficiency (WE), energy and atmosphere (EA), materials and resources (MR), indoor environmental quality (IE), and innovation and regional priority (RP).

The scoring system has a maximum score of 100 points, plus there are up to 10 additional bonus points for complying with two special categories: innovation and regional priority, which is the only site adequation that LEED provides.

\subsubsection{Weight Per UOI on Each GBRS}

In Figure 16, the results show the percentage of influence by UOI per category. In more advanced GBRSs like DGNB and HQE, the results are shown by IDS while the results in the BREEAM graph are shown by CRS. Finally, LEED results are not influenced by any weighting coefficient, thus all CRS provide the same influence.

BREEAM materials and land use and ecology are the most relevant UOI in terms of final scoring, with more than $1.5 \%$ final score influence. On the other hand, management, transport, and waste are less relevant with less than $0.5 \%$ of the final weight. DGNB economic quality UOI are the most relevant to the final score with an influence of $1.9 \%$, while process quality only provides $0.2 \%$ of the final weight. The HQE health category UOI provides $1.0 \%$ of the final weight to become the most important category by weight, while energy is the least important with less than $0.5 \%$. As previously stated, in LEED, all UOI are same importance in terms of final score. As presumed, those GBRSs with a higher number of UOI, DGNB, and HQE, provided less weight per UOI than those with GBRS, BREEAM, and LEED, which had a smaller number of them.

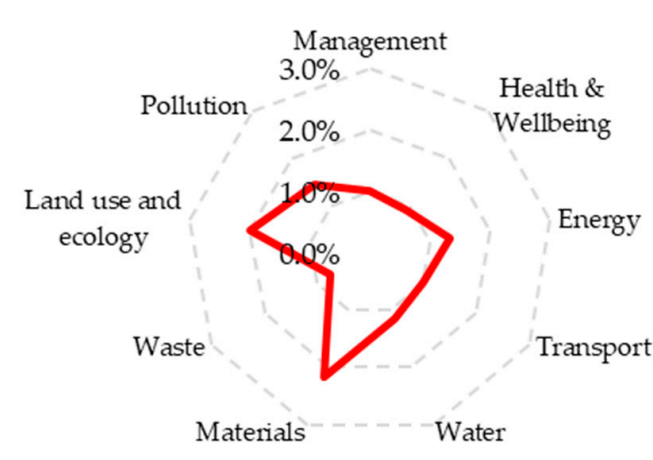

(a) BREEAM: Weight/CRS

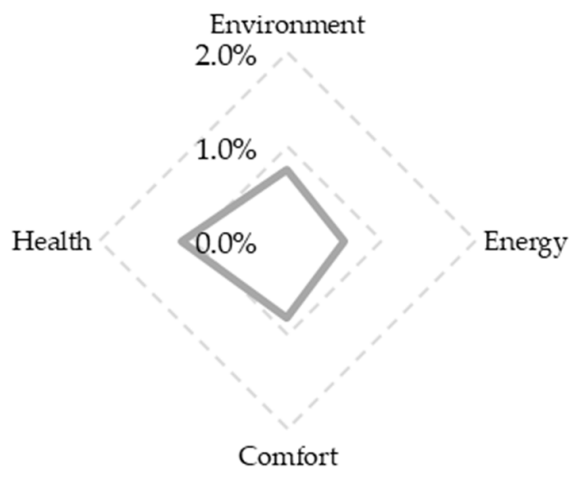

(c) HQE: Weight/IDS

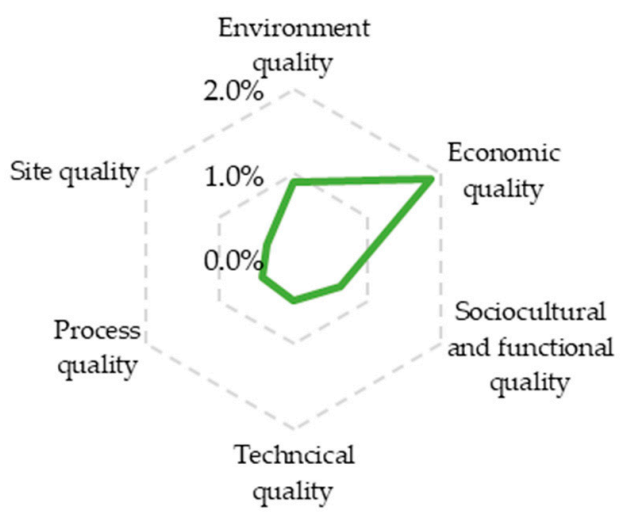

(b) DGNB: Weight/IDS

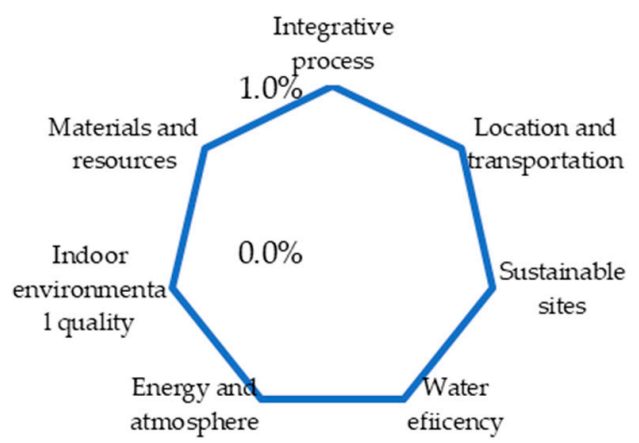

(d) LEED: Weight/CRS

Figure 16. Weight associated with UOI: (a) CRS in BREEAM; (b) IDS in DGNB; (c) IDS in HQE; (d) CRS in IDS. 


\subsection{Synergies between Level(s) and Other GBRSs}

The results were compiled with the objective to show a comparison between Level(s) and BREEAM, DGNB, HQE, and LEED. As detailed before in Section 3.4, the scoring process is different from one GBRS to another, thus synergies between GBRSs cannot be fully estimated in the same conditions. DGNB and HQE provide full details about their IDS, thus their results can be considered to be highly accurate, specifically, the latest version of DGNB, which provides a comprehensive description of the synergies between it and Level(s). On the other hand, the IDS from BREEAM and LEED were obtained by author interpretation because they use different methodologies where the UOI are CRS instead of IDS (see Table 2). These results could be considered as less accurate than those obtained in DGNB and HQE, thus it will be carefully discussed in the following section.

In Table 6, the synergies between GBRS and Level(s) are described in groups of two columns. For each GBRS, the column on the left explains the percentage influenced by Level(s), while the column on the right shows if this CAS is included within every GBRS. As described in the table, DGNB is the only GBRS to include six CAS described in Level(s). BREEAM includes all CAS, except Optimised life cycle cost and value. LEED and HQE include only four CAS, and do not include either the CAT 5 Adaptation and resilience to climate change or CAT 6 Optimised life cycle cost and value.

Table 4 and Figure 17 show the IDS influence breakdown, where the percentage of every GBRS in line with Level(s) is included. Figures inside the table are later shown in the graphs of the above-mentioned figure. Here, the final score influences were $21.1 \%$ in DGNB, $39.2 \%$ in HQE, $42.6 \%$ in BREEAM, and $66.0 \%$ in LEED.

Table 6. Synergies between the GBRS and Level(s).

\begin{tabular}{cccccccccccc}
\hline Level(s) & & \multicolumn{1}{c}{ BREEAM } & \multicolumn{2}{c}{ DGNB } & \multicolumn{2}{c}{ HQE } & \multicolumn{2}{c}{ LEED } \\
\hline CAS & CRS & IDS & $\%$ & INC & $\%$ & INC & $\%$ & INC & $\%$ & INC \\
\hline $\begin{array}{c}\text { Greenhouse gas emissions along a building's life } \\
\text { cycle }\end{array}$ & 1 & 2 & 20.0 & $\bullet$ & 3.60 & $\bullet$ & 5.03 & $\bullet$ & 33.0 & $\bullet$ \\
\hline $\begin{array}{c}\text { Resource efficient and circular material life cycles } \\
\text { Efficient use of water resources }\end{array}$ & 4 & 1 & 8.9 & $\bullet$ & 11.25 & $\bullet$ & 5.77 & $\bullet$ & 13.0 & $\bullet$ \\
\hline Healthy and comfortable spaces & 2 & 1 & 7.0 & $\bullet$ & 0.64 & $\bullet$ & 7.14 & $\bullet$ & 11.0 & $\bullet$ \\
\hline Adaptation and resilience to climate change & 1 & 1 & 0.6 & $\bullet$ & 0.86 & $\bullet$ & & & & \\
\hline Optimised life cycle cost and value & 2 & 1 & & & 0.36 & $\bullet$ & & & \\
\hline & 11 & 7 & 42.6 & & 21.1 & & 39.2 & & 66.0 & \\
\hline
\end{tabular}

- Indicators from Level(s) included (INC) in each GBRS.

$\square$ Greenhouse gas emissiones
along a buildings life cycle
$\square$ Resource efficient and
circular material life cycles
$\square$ Efficient use of water
resources
$\square$ Healthy and comfortable
spaces
$\square$ Adaptation and resilience
to climate change
$\square$ Optimised life cycle cost
and value

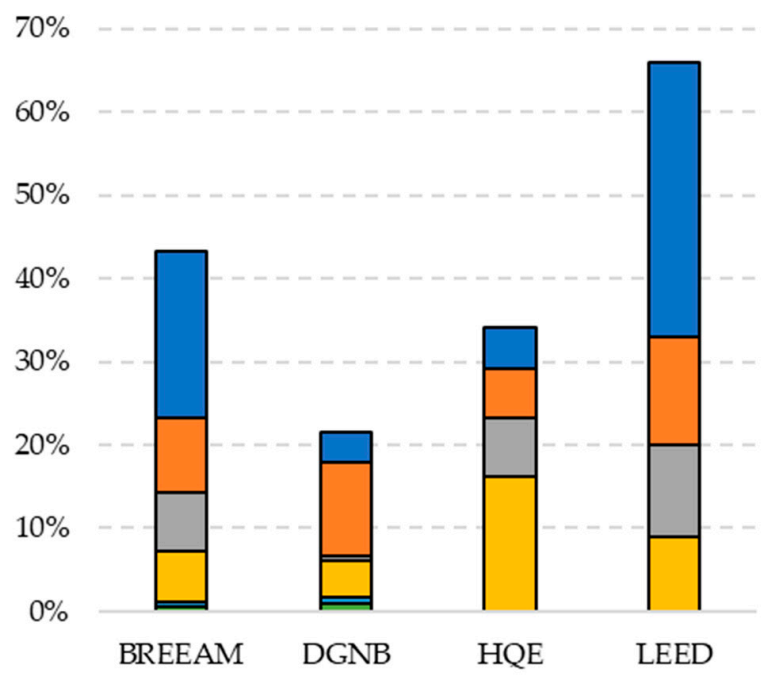

Figure 17. UOI weight breakdown per GBRS showing LEVEL(s) influence on the final score. 


\section{Discussion}

\subsection{Assessment Trends in GBRS within the EU}

The results shown in Figure 6 from Section 3.1 indicate a significant difference between the number of buildings that finally obtained a certification with those only registered. This may happen due to several reasons, highlighting the difficulty of the process in time, cost, and professional skills needed [82]. It is not yet certain as to whether the appearance of Level(s) will provide an increase in the already existing GBRS assessments, or, on the contrary, may produce a displacement from the current ones to it. As mentioned in Section 3.3, Level(s) is available in direct or indirect use [61], which would still allow stakeholders to freely decide about which GBRS would be better suited for their building assessment.

In Figure 7 in Section 3.1, the data reflects which one of the existing GBRSs within the EU are more widely used by stakeholders, where BREEAM, HQE, LEED and DGNB in this order are the most accepted. This seems to be related to the maturity of the process, but also with the strength of the organization supporting the GBRS. According to Section 3.4, BREEAM was born in 1990, HQE in 1997, and LEED in 1998. This is why it is likely that they already had a strong presence in the market before the appearance of the other GBRS. However, DGNB started in 2009 and grew fast to become the fourth ranked GBRS in the EU in terms of the number of buildings assessed. BREEAM in the UK, DGNB in Germany, HQE in France, and LEED in the USA, are supported by BRE, DGNB, CERNWAY and the US GBC. DGNB and HQE are members of the G17 Alliance, born with the aim of helping with the successful application of the UN SDGs [79]. Additionally, other councils included in Figure 6 such as the SGBC in Spain and OGNB in Austria are members of the G17 Alliance. This may produce a different response into two different kinds of GBRS: on one hand, those members of the G17 Alliance with the aim to enhance homogeneity of some common indicators, but on the other hand, those truly internationally implanted (BREEAM and LEED), which will probably keep on developing their own methodologies to pursue SDGs, but without converging with Level(s) indicators.

Finally, the results in this section are influenced by the range defined in the methodology (see Section 2.1), thus any modification to it by introducing urban developments or in use assessments may provide significant changes, but these would not be included in the typologies covered by Level(s). As soon as Level(s) enlarges the scope of its included typologies, the results within this section should be revised carefully.

\subsection{Research Trends and Critical Review of Current GBRS within the EU}

Trends on research from 2008 are included in Section 3.2. There, only BREEAM, DGNB, HQE and LEED were included, according to the aims of this research. The total number of papers carefully analysed, 1169, provides the first conclusion: most of research papers in English since 2008 were focused on LEED while BREEAM was in the medium range, and only a few included DGNB and HQE. Despite the results in Figure 8, the data in Figure 9 show the evident conclusion that there were only very few papers that included a comparison between BREEAM, DGNB, HQE, and LEED in any possible combination. Usually, papers including DGNB and HQE provide a comparison between them and others. Language filter may be one reason, thus future research should consider the impact on the search using different languages, mainly French and German. Level(s) was included in this search but it produced no results, which may be because it is still a work in progress whose first draft was released in 2018 [61].

From all of the data classified, only those belonging to journals with SCI classified Q1 and Q2 were considered for this research, and more relevant journals are presented in Figure 10 and Table 2 to provide a classification of them. These may have influenced this research; thus, future research could include some exceptional works appearing in less relevant journals. In any case, the quartile of a journal is not a still photo, since it can vary from year to year. 


\section{3. $R A$ and NT in GRBS Assessment}

As Figure 13 shows, most of the relevant research from 2008 was focused in Asia, the EU, or MENA regions and less in NA. BREAM (UK) and LEED (US) had an earlier development and the research is probably more mature than in other regions. Research focused on developing regions like Asia and MENA as well as those focused on small developed countries within the EU seem to need adaptations of current GBRSs to local conditions. This means that $41 \%$ of relevant papers were focused on RA or NT development (see Figure 11). The RA of existing GBRSs has lately been a trend for researchers in locations like Jordan [83], Saudi Arabia [84,85], Pakistan [86], and Iran [87]. These studies usually use BREAM, LEED, or SBTool as a source to define scoring methodology and IDS. In particular, LEED includes a regional priority category that may bring four extra points [88], which is less than $4 \%$ of the final score. On the contrary, BREEAM seems fully adapted to some countries via cooperation agreements with local institutes, but there are only a few (see Table 1). For those countries where there is still no cooperation agreement between BREEAM and local institutions, it includes specific weightings per country as well as some climatic influence applied to credit scores [28]. The amount of RA research has created doubt on the validity of the most common used GBRS at the international Level and if they can improve their RA. Level(s) is somehow a public effort to create a wide framework that can mitigate the need for continuous adaptations of GBRSs per country. Its use may reduce the need for national stakeholders to develop a new GBRS. Considering this scenario with many GBRS and different versions, some authors are working on the need to provide some helping tools for stakeholders to choose the most appropriate GRBS for each project, depending on factors such as location [84], project delivery attributes [82], and available credits [89]. These will probably be affected by the introduction of Level(s) because of two reasons: first, Level(s) provides a framework of simplicity and transparency in comparison with the other GBRS, and second, it is pushing the EU GBRS to make convergence efforts.

Other authors have proceeded with the improvement of current GBRSs in terms of holistic sustainability [81]. LEED and BREEAM, as pioneers, have focused on ENV sustainability, thus these authors are working on an improvement of SOC [90,91] and ECO [92] sustainability. In contrast, the HQE score is highly influenced by SOC sustainability and the latest version of DGNB already states a similar weight for the ENV, SOC, and ECO pillars. Certainly, it is the first GBRS to achieve a robust score system that is truly holistic. Level(s) was also developed with the idea to also provide holistic sustainability and so it is not as mature as DGNB in this field. From the 13 IDS included in it, eight correspond to ENV, two to SCO, and three to ECO sustainability pillars. However, these may be amended through the introduction of some weighting factors.

\subsection{Trends in GRBS Assessment Comparison}

Instead of using a NT or RA approach, 36\% of authors focused in providing GBRSC (see Figure 12), and according to their research, deepness was classified into 5\% CAS, 36\% ISS, and 59\% IDS, as defined in Section 2.3. A sub-category comparison and the way holistic sustainability is reached $[15,20]$ was not considered in this research due to its main objective. Authors have considered establishing a GBRSC at the IDS Level focused on a specific category [16,93,94] or case study [46,94-97]. According to Level(s), IDS analysis is a matter of importance when trying to compare other GBRSs. It requires organizing the BREEAM, DGNB, HQE, and LEED into a similar structure composed of CAS, ISS, CRS, and IDS, which is not easy when the UOI changes from one to another. DGNB and HQE have a LCA approach more like Level(s) (see Sections 3.4.2 and 3.4.3), while the BREEAM and LEED structure is quite different. These differences in proceedings causes some difficulties in quantifying the synergies between Level(s) and the other GBRSs. This is likely to be done with some development of any of these GBRS, especially BREEAM and LEED, to improve the adequacy to Level(s). Only DGNB in its latest version includes a synergies section with Level(s). HQE does not include a Level(s) synergies section, but according to its methodology, it has been easier to provide a comparison with Level(s). 


\subsection{Level(s) Scoring Influence on (IDS) of the Existing GBRS}

According to the results in Table 6, DGNB is the only GBRS that includes in its UOI all IDS from Level(s). BREEAM includes only five of them, and HQE and LEED include only four. Even with this in mind, DGNB seems to be less affected by Level(s) (21.1\%) than HQE (39.2\%), BREEAM (42.6\%), and LEED $(66.0 \%)$, which is a significant deviation. This may have been produced by an accumulative mistake when the methodology was applied to compare the GBRS. In Figure 17, the UOI weight breakdown shows which Level(s) category presented a more significant deviation. In BREEAM and LEED, Greenhouse gas emissions along a building's life cycle had an influence of $20.0 \%$ and $33.0 \%$, respectively, which is consistent with the methodology applied. The Energy CAS in BREEAM and Energy an Atmosphere CAS in LEED were considered as fully affected. Additionally, HQE Healthy and comfortable spaces had a 16.1\% influence on the HQE final score because the weight of the Comfort CAS in IT. As LEED, BREEAM, and HQE do not provide specific synergies, results from the methodology in Section 2.3 assigned influence at every IDS with a potential relationship. Future versions of BREEAM, $\mathrm{HQE}$, and LEED may include an alignment section with Level(s).

\section{Conclusions}

Level(s) intends to improve building sustainability within the EU region and comes at time of maturity but confusion. Several GBRSs have already been established with thousands of assessments already provided, but their processes are not the same. Usually, this provides confusion to stakeholders, which slows down the spread of the sustainability process.

This paper demonstrates the heterogeneity of current GRBS in the EU scenario and the difference between sustainability assessments, where DGNB seems to be more aligned with the current EU framework.

Efforts to provide knowledge, regional adaptation, or helping tools for the most relevant GBRS have been undertaken by researchers, which gives the impression of the difficulty to give universal solutions.

The Level(s) proposal is intended to partially solve this confusing scenario with a simple structure of common indicators based on EU regulations, proceedings, and tools of common use by professionals. At least it seems to be producing a boosting effect in other GBRSs to search for European alignment. DGNB is the first of its class that has specifically introduced a section focused on synergies with Level(s) and it will probably not be the only one as the G17 Alliance is intended for that, especially HQE, whose methodology seems to be easily adaptable to it.

Considering the last international version of the GBRS manual, BREEAM and LEED are more influenced by Level(s). Their current structure is not intended to provide holistic sustainability because they still provide much more weight to the environmental pillar than to the others. Although every GBRS provides a differentiated structure with a different number of CAS and IDS, all of them rely on a UOI that can be compared. Trends in GBRS seem to lead to a simplification based on three macro-categories with a similar weight: environmental, economic and social, and a better alignment between the GBRS and EU policies.

Several interesting questions worth expanding in the future have arisen from the results obtained in this research.

Attention to upcoming versions of Level(s) as well as BREAM, HQE, and LEED has a vital interest in supervising the alignment of these GBRSs to the new EU framework and determine if this guide to the simplification and homogenization of the sustainability assessment process will succeed. This will definitively help to find a way to pursue a circular economy and the fulfilment of the SDGs proposed by the UN.

In light of these big challenges, future research should focus on the development of specific CAS that allow for a deeper comparison between UOI. Detailed research on specific topics will increase the alignment and robustness of the whole process, thus helping to strengthen existing GBRSs and Level(s). 
Author Contributions: A.S.C. wrote the article, S.G.M. checked the manuscript and carried out the revision, and J.M.A.M. supervised and reviewed all of work and manuscript. All authors have read and agreed to the published version of the manuscript.

Funding: This research received no external funding.

Acknowledgments: The authors gratefully acknowledge the contribution of several institutions: EDGE and GBCE provided us a comprehensive list of certified buildings with EDGE and Verde, and DGNB GmbH provided us DGNB 2020 international version.

Conflicts of Interest: The authors declare no conflicts of interest.

Abbreviation

\begin{tabular}{|c|c|}
\hline BRE & Building research establishment \\
\hline BREEAM & Building research establishment environmental assessment method \\
\hline DGNB & Deutsche gesellschaft für nachhaltigies bauen \\
\hline CAS & Categories system \\
\hline CASBEE & Comprehensive assessment system for built efficiency \\
\hline CRS & Criterion systems \\
\hline EC & European commission \\
\hline $\mathrm{ECO}$ & Economic \\
\hline ENV & Environmental \\
\hline ESGB & Evaluation standard for green buildings \\
\hline EU & European Union \\
\hline GBC & Green building council \\
\hline GBRS & Green building rating system \\
\hline HQE & Haute qualité environnementale \\
\hline IDS & Indicators system \\
\hline INS & Institutional \\
\hline ISS & Issues system \\
\hline ITACA & Instituto per l'innovazione e trasparenza degli appalti e la compatibilita ambientale \\
\hline LEED & Leadership in Energy and Environmental Design \\
\hline JRC & Joint research centre \\
\hline MEB & Minimum energy buildings \\
\hline MENA & Middle East and North Africa \\
\hline MOUHURD & Ministry of Urban Housing and Rural Development \\
\hline NA & North America \\
\hline NT & New tool \\
\hline RA & Reginal adaptation \\
\hline SBTool & Sustainable building tool \\
\hline $\mathrm{SCO}$ & Scopus \\
\hline SDG & Sustainable Development Goals \\
\hline SOC & Social \\
\hline TQB & Total quality building assessment \\
\hline UCLG & United cities and local government \\
\hline UNECE & United Nations Economic Commission for Europe \\
\hline UOI & Users operation item \\
\hline WGBC & World Green Building Council \\
\hline WOS & Web of Science \\
\hline
\end{tabular}




\section{Appendix A}

Table A1. Most Relevant Authors According to New Development Tools and/or Regional Adaptation from 2008 to 2019.

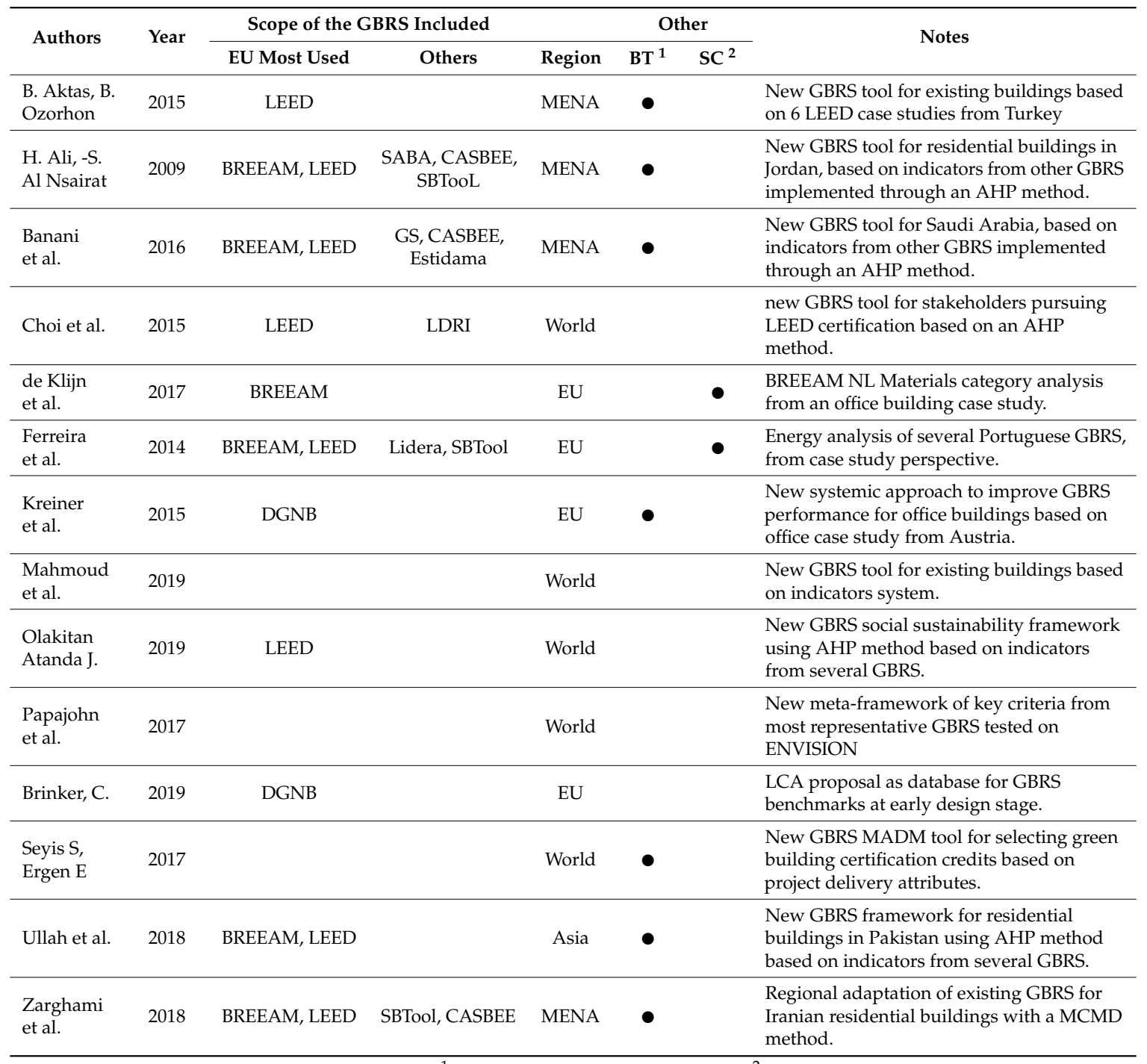

- Main research objective included: ${ }^{1}$ Building typology focused (BT), ${ }^{2}$ Single category focused (SC).

Table A2. Most Relevant Authors According to GBRS Comparison from 2008 to 2019.

\begin{tabular}{|c|c|c|c|c|c|c|c|c|}
\hline \multirow{2}{*}{ Authors } & \multirow{2}{*}{ Year } & \multicolumn{2}{|c|}{ Scope of the GBRS Included } & \multirow[b]{2}{*}{ Region } & \multicolumn{3}{|c|}{ GBRSC } & \multirow{2}{*}{ Notes } \\
\hline & & EU Most Used & Others & & CAS $^{1}$ & ISS $^{2}$ & IDS $^{3}$ & \\
\hline $\begin{array}{l}\text { Asdrubali } \\
\text { et al. }\end{array}$ & 2015 & LEED & Itaca & $\mathrm{EU}$ & $\bullet$ & $\bullet$ & $\bullet$ & $\begin{array}{l}\text { LEED and ITACA methodology } \\
\text { comparison from a residential case study. }\end{array}$ \\
\hline Awadth O. & 2017 & BREEAM, LEED & Estidama, GSAS & MENA & $\bullet$ & $\bullet$ & $\bullet$ & $\begin{array}{l}\text { Energy and water categories } \\
\text { comparison. }\end{array}$ \\
\hline $\begin{array}{l}\text { Bernardi } \\
\text { et al. }\end{array}$ & 2017 & $\begin{array}{l}\text { BREEAM, } \\
\text { DGNB, HQE, } \\
\text { LEED }\end{array}$ & CASBEE, SBTool & World & $\bullet$ & $\bullet$ & & $\begin{array}{l}\text { Overview of most representative GBRS } \\
\text { in the world. }\end{array}$ \\
\hline $\begin{array}{l}\text { Chen } \mathrm{H} \text {, } \\
\text { Lee WL }\end{array}$ & 2013 & LEED & BEAM Plus & Asia & $\bullet$ & $\bullet$ & $\bullet$ & $\begin{array}{l}\text { LEED and BEAM Plus methodology } \\
\text { comparison from a office building case } \\
\text { study perspective focused in energy } \\
\text { category. }\end{array}$ \\
\hline $\begin{array}{l}\text { Dat Tien } \\
\text { Doan et al. }\end{array}$ & 2017 & BREEAM, LEED & CASBEE. GS & World & $\bullet$ & $\bullet$ & $\bullet$ & $\begin{array}{l}\text { Sub-Categories comparison of most } \\
\text { representative GBRS }\end{array}$ \\
\hline
\end{tabular}


Table A2. Cont.

\begin{tabular}{|c|c|c|c|c|c|c|c|c|}
\hline Dias et al. & 2017 & & & World & $\bullet$ & $\bullet$ & $\bullet$ & $\begin{array}{l}\text { Dependences among LEED indicators } \\
\text { from } 10 \text { office building case study } \\
\text { perspective. }\end{array}$ \\
\hline He et al. & 2018 & LEED & GS, ASGB & Asia & $\bullet$ & $\bullet$ & $\bullet$ & $\begin{array}{l}\text { Design influence of LEED, GS and ASGB, } \\
\text { from case study perspective of an } \\
\text { educational building. }\end{array}$ \\
\hline Hu et al. & 2017 & LEED & $\begin{array}{l}\text { Living Building } \\
\text { Challenge }\end{array}$ & NA & $\bullet$ & $\bullet$ & $\bullet$ & $\begin{array}{l}\text { Energy category comparison of several } \\
\text { GBRS from different cases study } \\
\text { perspective. }\end{array}$ \\
\hline $\begin{array}{l}\text { Illankoon } \\
\text { et al. }\end{array}$ & 2017 & BREEAM, LEED & $\begin{array}{l}\text { GS, GM, } \\
\text { CASBEE, BEAM } \\
\text { Plus, GBI, IGBC }\end{array}$ & Asia & $\bullet$ & $\bullet$ & $\bullet$ & $\begin{array}{l}\text { key criteria comparison of most } \\
\text { representative GBRS in the Asia, to } \\
\text { provide foundations of new GBRS tools } \\
\text { in the future. }\end{array}$ \\
\hline Ismaell W. & 2018 & $\begin{array}{l}\text { BREEAM, LEED } \\
\text { DGNB }\end{array}$ & $\begin{array}{l}\text { GS, GG, GBTooL } \\
\text { CASBEE }\end{array}$ & World & $\bullet$ & $\bullet$ & & $\begin{array}{l}\text { Comparison of most representative } \\
\text { GBRS, with special attendance to } \\
\text { midpoint and endpoint methodology. }\end{array}$ \\
\hline Lee, W.L. & 2012 & BREEAM, LEED & $\begin{array}{l}\text { BEAM-Plus, } \\
\text { CASBEE }\end{array}$ & Asia & $\bullet$ & $\bullet$ & $\bullet$ & $\begin{array}{l}\text { Energy category comparison of several } \\
\text { GBRS in Asia }\end{array}$ \\
\hline Lee et al. & 2008 & BREEAM, LEED & BEAM-Plus & Asia & $\bullet$ & $\bullet$ & $\bullet$ & $\begin{array}{l}\text { Energy category comparison of several } \\
\text { GBRS from a residential building case } \\
\text { study perspective. }\end{array}$ \\
\hline Li et al. & 2017 & & $\begin{array}{l}\text { CASBEE, GS, } \\
\text { SBTool, BEAM } \\
\text { Plus }\end{array}$ & Asia & $\bullet$ & $\bullet$ & & $\begin{array}{l}\text { Categories comparison of most } \\
\text { representative GBRS in the Asia. }\end{array}$ \\
\hline Lu et al. & 2019 & LEED & $\begin{array}{l}\text { GBEL, BEAM } \\
\text { Plus }\end{array}$ & Asia & $\bullet$ & $\bullet$ & & Waste categories comparison. \\
\hline Park et al. & 2017 & BREEAM, LEED & $\begin{array}{l}\text { CASBEE, LBC, } \\
\text { SEED }\end{array}$ & Asia & $\bullet$ & $\bullet$ & $\bullet$ & Material categories comparison. \\
\hline Seinre et al. & 2014 & BREEAM, LEED & & EU & $\bullet$ & $\bullet$ & & $\begin{array}{l}\text { Categories weighting improvement for } \\
\text { existing GBRS in Estonia, from an office } \\
\text { case study perspective. }\end{array}$ \\
\hline $\begin{array}{l}\text { Stender } \\
\text { et al. }\end{array}$ & 2019 & DGNB & & EU & & & & $\begin{array}{l}\text { Social impacts in urban communities } \\
\text { from a DGNB case study assessment. }\end{array}$ \\
\hline $\begin{array}{l}\text { Zhang } \\
\text { et al. }\end{array}$ & 2019 & BREEAM, LEED & ESGB, EEWH & Asia & $\bullet$ & $\bullet$ & & $\begin{array}{l}\text { Categories comparison between GBRS in } \\
\text { China. }\end{array}$ \\
\hline Zou Y. & 2019 & BREEAM & ESGB & Asia & $\bullet$ & $\bullet$ & & $\begin{array}{l}\text { Comparison between LEED and ESGB, } \\
\text { with special attendance to Chinese } \\
\text { market evolution. }\end{array}$ \\
\hline
\end{tabular}

- Main research objective included: ${ }^{1}$ Category system (CAS), ${ }^{2}$ Issues system (ISS), ${ }^{3}$ Indicator system (IDS).

\section{References and Note}

1. Nejat, P.; Jomehzadeh, F.; Taheri, M.M.; Gohari, M.; Majid, M.Z.A. A global review of energy consumption, $\mathrm{CO}_{2}$ emissions and policy in the residential sector (with an overview of the top ten $\mathrm{CO}_{2}$ emitting countries). Renew. Sustain. Energy Rev. 2015, 43, 843-862. [CrossRef]

2. Martínez-Zarzoso, I.; Maruotti, A. The impact of urbanization on $\mathrm{CO}_{2}$ emissions: Evidence from developing countries. Ecol. Econ. 2011, 70, 1344-1353. [CrossRef]

3. Pérez-Lombard, L.; Ortiz, J.; Pout, C. A review on buildings energy consumption information. Energy Build. 2008, 40, 394-398. [CrossRef]

4. Li, M.; Li, L.; Strielkowski, W. The impact of urbanization and industrialization on energy security: A case study of China. Energies 2019, 12, 2194. [CrossRef] 
5. Edenhofer, O.; Pichs-Madruga, R.; Sokona, Y.; Farahani, E.; Kadner, S.; Seyboth, K.; Adler, A.; Baum, I.; Brunner, S.; Eickemeier, P.; et al. Climate Change 2014: Mitigation of Climate Change. Contribution of Working Group III to the Fifth Assessment Report of the Intergovernmental Panel on Climate Change; Cambridge University Press: Cambridge, UK; New York, NY, USA, 2014.

6. Wang, C.N.; Ho, H.X.T.; Hsueh, M.H. An integrated approach for estimating the energy efficiency of seventeen countries. Energies 2017, 10, 1597. [CrossRef]

7. Wang, L.W.; Le, K.D.; Nguyen, T.D. Assessment of the energy efficiency improvement of twenty-five countries: A DEA approach. Energies 2019, 12, 1535. [CrossRef]

8. Assembly, T.G.; Goals, T. 271015_EN_A_RES_70_1_transforming_our_world. 16301, October, 1-35, 2015.

9. European Commission. European Action for Sustainability: Next Steps for a Sustainable European Future. In Proceedings of the Communication from the Commission to the European Parliament, the Council, the European Economic and Social Committee and the Committee of the Regions, Strasbourg, France, 22 November 2016.

10. United Nations Economic Commission for Europe. SDG Priorities. 2019. Available online: https://www.unece. org/sustainable-development/sdg-priorities.html (accessed on 22 October 2019).

11. European Commission. Circular Economy. Implementation of The Circular Economy Action Plan. 2019. Available online: https://ec.europa.eu/environment/circular-economy/index_en.htm (accessed on 26 October 2019).

12. European Commission. Resource efficiency opportunities in the building sector. In Proceedings of the Communication from the Commission to the European Parliament, the Council, the European Economic and Social Committee and the Committee of the Regions, Brussels, Belgium, 1 July 2016.

13. Bernardi, E.; Carlucci, S.; Cornaro, C.; Bohne, R.A. An Analysis of the Most Adopted Rating Systems for Assessing the Environmental Impact of Buildings. Sustainability 2017, 9, 1226. [CrossRef]

14. Mattoni, B.; Guattari, C.; Evangelisti, L.; Bisegna, F.; Gori, P.; Asdrubali, F. Critical review and methodological approach to evaluate the differences among international green building rating tools. Renew. Sustain. Energy Rev. 2018, 82, 950-960. [CrossRef]

15. Melgar, S.G.; Bohórquez, M.Á.M.; Márquez, J.M.A. UhuMEB: Design, construction, and management methodology of minimum energy buildings in subtropical climates. Energies 2018, 11, 2745. [CrossRef]

16. De Klijn-Chevalerias, M.; Javed, S. The Dutch approach for assessing and reducing environmental impacts of building materials. Build. Environ. 2017, 111, 147-159. [CrossRef]

17. Lu, W.; Chi, B.; Bao, Z.; Zetkulic, A. Evaluating the effects of green building on construction waste management: A comparative study of three green building rating systems. Build. Environ. 2019, 155, 247-256. [CrossRef]

18. Eriksson, O.; Finnveden, G. Energy recovery from waste incineration-The importance of technology data and system boundaries on $\mathrm{CO}_{2}$ emissions. Energies 2017, 10, 539. [CrossRef]

19. Doan, D.T.; Ghaffarianhoseini, A.; Naismith, N.; Zhang, T.; Ghaffarianhoseini, A.; Tookey, J. A critical comparison of green building rating systems. Build. Environ. 2017, 123, 243-260. [CrossRef]

20. Berardi, U. Clarifying the new interpretations of the concept of sustainable building. Sustain. Cities Soc. 2013, 8, 72-78. [CrossRef]

21. Friedmann, W.; Munro, L. United Nations. Int. J. 2010, 16, 102. [CrossRef]

22. Littig, B.; Griessler, E. Social sustainability: A catchword between political pragmatism and social theory. Int. J. Sustain. Dev. 2006, 8, 65. [CrossRef]

23. Culture: Fourth Pillar of Sustainable Development; United Cities Local Government Policy Statement: Barcelona, Spain, 2010.

24. Awadh, O. Sustainability and green building rating systems: LEED, BREEAM, GSAS andEstidama critical analysis. J. Build. Eng. 2017, 11, 25-29. [CrossRef]

25. Ferreira, J.; Pinheiro, M.D.; de Brito, J. Portuguese sustainable construction assessment tools benchmarked with BREEAM and LEED: An energy analysis. Energy Build 2014, 69, 451-463. [CrossRef]

26. Qian, W.; Kaur, A.; Schaltegger, S. Managing Eco-Efficiency Development for Sustainability: An Investigation of Top Carbon Polluters in Australia. In Accounting for Sustainability: Asia Pacific Perspectives; Springer: Cham, Switzerland, 2018; Volume 33, pp. 103-124.

27. Lee, W.L. Benchmarking energy use of building environmental assessment schemes. Energy Build. 2012, 45, 326-334. [CrossRef] 
28. BRE Global. BREEAM International New Construction 2016; BRE Global: Watford, UK, 2017; Available online: https://hbreavis.com/wp-content/uploads/2017/06/BREEAM-International-New-Construction-2016. pdf (accessed on 18 October 2019).

29. U.S. Green Building Council. LEED v4.1|USGBC. 2019. Available online: https://new.usgbc.org/leed-v41 (accessed on 12 September 2019).

30. DGNB System-Certificate for Sustainable and Green Building; DGNB GmbH: Stuttgart, Germany, 2019.

31. Cerway. HQE Certification. 2019. Available online: https://www.behqe.com/\# (accessed on 18 October 2019).

32. Varma, C.R.S.; Palaniappan, S. Comparision of green building rating schemes used in North America, Europe and Asia. Habitat Int. 2019, 89, 101989. [CrossRef]

33. CASBEE Certification System; Japan Sustainable Building Consortium: Tokyo, Japan, 2019.

34. Green Building Council Australia. Green Star Rating System / Green Building Council of Australia. 2019. Available online: https://new.gbca.org.au/green-star/rating-system/ (accessed on 12 September 2019).

35. Ding, Z.; Fan, Z.; Tam, V.W.; Bian, Y.; Li, S.; Illankoon IC, S.; Moon, S. Green building evaluation system implementation. Build. Environ. 2018, 133, 32-40. [CrossRef]

36. Zhang, X.; Zhan, C.; Wang, X.; Li, G. Asian green building rating tools: A comparative study on scoring methods of quantitative evaluation systems. J. Clean. Prod. 2019, 218, 880-895. [CrossRef]

37. Building Research Establishment Group. BREEAM Worlwide. 2019. Available online: https://www.breeam. com/worldwide/ (accessed on 18 October 2019).

38. Building Research Establishment Environmental Assessment Method ES. 2019. Available online: http: //www.breeam.es/ (accessed on 4 November 2019).

39. Dutch Green Building Council. BREEAM-NL. 2019. Available online: https://www.breeam.nl/ (accessed on 4 November 2019).

40. TÜV SÜD Industrie Service GmbH. DIFNI. BREEAM DE. 2019. Available online: https://difni.de/breeam/ breeam-de/ (accessed on 18 October 2019).

41. Norwegian Green Building Council. BREEAM NW. 2019. Available online: https://byggalliansen.no/ sertifisering/ (accessed on 18 October 2019).

42. Stahan, K. Energy-efficient architecture in sustainable urban tourism. Prostor 2014, 22, 279-290.

43. CR, G.B.C. SBToolCZ. 2018. Available online: https://www.sbtool.cz/cs/ (accessed on 18 October 2019).

44. Andrade, J.; Braganca, L. Sustainability assessment of dwellings-A comparison of methodologies. Civ. Eng. Environ. Syst. 2016, 33, 125-146. [CrossRef]

45. Italia, I. ITACA. 2019. Available online: http://www.iisbeitalia.org/ (accessed on 18 October 2019).

46. Asdrubali, F.; Baldinelli, G.; Bianchi, F.; Sambuco, S. A comparison between environmental sustainability rating systems LEED and ITACA for residential buildings. Build. Environ. 2015, 86, 98-108. [CrossRef]

47. Macias, M.; Garcia Navarro, J. VERDE, a methodology and tool for a sustainable building assessment. Inf. LA Constr. 2010, 62, 87-100.

48. Green Building Council España. GBCe | Certificación VERDE. 2019. Available online: https://gbce.es/ certificacion-verde/ (accessed on 12 September 2019).

49. Austrian Institute for Building Biology and Ecology. ASBC TQB Assessment. 2019. Available online: https://www.oegnb.net/en/tqb.htm (accessed on 12 September 2019).

50. Minergie. Minergie ECO. 2019. Available online: https://www.minergie.ch/it/ (accessed on 18 October 2019).

51. Peyramale, V.; Eberl, S.; Essig, N. OPEN HOUSE: An online platform for a transparent and open methodology to assess the sustainability of buildings. Int. J. Sustain. Build. Technol. Urban. Dev. 2012, 3, 316-321. [CrossRef]

52. ÖGNB. TQB Certification. 2019. Available online: https://www.oegnb.net/ablauf.htm (accessed on 18 October 2019).

53. DIFNI. BREEAM AT. 2019. Available online: https://difni.de/breeam/breeam-at/ (accessed on 18 October 2019).

54. German Sustainable Building Council GmbH. DGNB System-Scheme overview. 2019. Available online: https://www.dgnb-system.de/en/schemes/scheme-overview/ (accessed on 12 September 2019).

55. Green Building Council Italia. LEED Italia. 2019. Available online: http://www.gbcitalia.org/leed (accessed on 18 October 2019).

56. Swedish Green Building Council. Miljobyggnad Certification. 2019. Available online: https://www.sgbc.se/ certifiering/miljobyggnad/ (accessed on 18 October 2019).

57. Building Research Establishment Group. HQM Certification. 2019. Available online: https://www.homequalitymark. $\mathrm{com} /$ (accessed on 18 October 2019). 
58. Building Research Establishment Group. CEEQUAL Certification. 2019. Available online: https://www. ceequal.com/ (accessed on 18 October 2019).

59. Reader, L. Guide to Green Building Rating Systems: Understandung LEED, Green Globes, Energy Star, the National Green Building Standard, and More. Residential Rating Systems: A Comparison; John Wiley \& Sons: Hoboken, NJ, USA, 2011; pp. 1-25.

60. European Commission. LEVEL(S) Taking Action on the Total Impact of the Construction Sector; Publications Office of the European Union: Luxembourg, 2019.

61. Joint Reseach Centre. LEVEL(s) A Common EU Framework of Core Sustainability Indicators. 2019. Available online: https://susproc.jrc.ec.europa.eu/Efficient_Buildings/documents.html (accessed on 26 October 2019).

62. Pushkar, S.; Verbitsky, O. Strategies for leed certified projects: The building layer versus the service layer. Can. J. Civ. Eng. 2018, 45, 1065-1072. [CrossRef]

63. Cerway. Cerway-HQE Certification-High Environmental Quality-Référent Training. 2019. Available online: https://www.behqe.com/home (accessed on 12 September 2019).

64. U.S. Green Building Council. Projects | U.S. Green Building Council. 2019. Available online: https://www.usgbc. org/projects (accessed on 31 July 2019).

65. Building Research Establishment. BREEAM Projects. 2019. Available online: https://tools.breeam. $\mathrm{com} /$ projects/explore/map.jsp?sectionid $=0 \&$ projectType $=\&$ rating $=\&$ certNo $=\&$ buildingName $=\& c l i e n t=$ \&developer $=\&$ certBody $=\&$ assessor $=\&$ addressPostcode $=\&$ countryId $=\&$ partid $=10023 \&$ Submit $=$ Search (accessed on 31 July 2019).

66. German Sustainable Building Council GmbH. DGNB Pre-Certified and Certified Projects. 2019. Available online: https://www.dgnb-system.de/en/projects/ (accessed on 31 July 2019).

67. Certivea. CertiBOX. 2019. Available online: http://certibox.certivea.fr/system_certivea/axxone.php? TUFQL3BnZS1NQVBfYWNjdWVpbC5waHA= (accessed on 31 July 2019).

68. Nguyen, T.H.; Toroghi, S.H.; Jacobs, F. Automated Green Building Rating System for Building Designs. J. Archit. Eng. 2016, 22, 4. [CrossRef]

69. International Finance Corporation. EDGE Methodology Report | EDGE Buildings; International Finance Corporation: Washington, DC, USA, 2019.

70. Aghaei Chadegani, A.; Salehi, H.; Yunus, M.; Farhadi, H.; Fooladi, M.; Farhadi, M.; Ale Ebrahim, N. A comparison between two main academic literature collections: Web of science and scopus databases. Asian Soc. Sci. 2013, 9, 18-26. [CrossRef]

71. Wu, Z.; Shen, L.; Yu, A.T.W.; Zhang, X. A comparative analysis of waste management requirements between five green building rating systems for new residential buildings. J. Clean. Prod. 2016, 112, 895-902. [CrossRef]

72. Cerway. Assessment Scheme for the Environmental Performance of Non-Residential Building under Construction; Cerway: Paris, France, 2016.

73. Council, U.G.B. LEED v4.1 for Building Design and Construction; US Green Building Council: Washington, DC, USA, 2019.

74. Dodd, N.; Cordella, M.; Traverso, M.; Donatello, S. Level(s)—A Common EU Framework of Core Sustainability Indicators for Office and Residential Buildings: Parts 1 and 2, EUR 28899EN; Publications Office of the European Union: Luxembourg, 2017.

75. Dodd, N.; Cordella, M.; Traverso, M.; Donatello, S. Level(s)—A Common EU Framework of Core Sustainability Indicators for Office and Residential Buildings: Part 3, EUR 28898 EN; Publications Office of the European Union: Luxembourg, 2017.

76. German Sustainable Building Council. DGNB System International 2014 Version; DGNB GmbH: Stuttgart, Germany, 2014.

77. SCIMAGO LAB. SJR: Scientific Journal Rankings. 2019. Available online: https://www.scimagojr.com/ journalrank.php (accessed on 31 July 2019).

78. Falagas, M.E.; Kouranos, V.D.; Arencibia-Jorge, R.; Karageorgopoulos, D.E. Comparison of SCImago journal rank indicator with journal impact factor. FASEB J. 2008, 22, 2623-2628. [CrossRef] [PubMed]

79. G17. G17-European Green Building Councils Alliance Network. 2019. Available online: https://www.g17.eu/ (accessed on 8 November 2019).

80. Building Research Establishment Group. Our History | BRE Group. 2019. Available online: https://www. bregroup.com/about-us/our-history/ (accessed on 31 July 2019).

81. Keeble, B.R. The Brundtland Report: 'Our Common Future'. Med. War 1988, 4, 17-25. [CrossRef] 
82. Seyis, S.; Ergen, E. A decision-making support tool for selecting green building certification credits based on project delivery attributes. Build. Environ. 2017, 126, 107-118. [CrossRef]

83. Ali, H.H.; Al Nsairat, S.F. Developing a green building assessment tool for developing countries-Case of Jordan. Build. Environ. 2009, 44, 1053-1064. [CrossRef]

84. Alyami, S.H.; Rezgui, Y. Sustainable building assessment tool development approach. Sustain. Cities Soc. 2012, 5, 52-62. [CrossRef]

85. Banani, R.; Vahdati, M.M.; Shahrestani, M.; Clements-Croome, D. The development of building assessment criteria framework for sustainable non-residential buildings in Saudi Arabia. Sustain. Cities Soc. 2016, 26, 289-305. [CrossRef]

86. Ullah, W.; Noor, S.; Tariq, A. The development of a basic framework for the sustainability of residential buildings in Pakistan. Sustain. Cities Soc. 2018, 40, 365-371. [CrossRef]

87. Zarghami, E.; Azemati, H.; Fatourehchi, D.; Karamloo, M. Customizing well-known sustainability assessment tools for Iranian residential buildings using Fuzzy Analytic Hierarchy Process. Build. Environ. 2018, 128, 107-128. [CrossRef]

88. Pushkar, S. The effect of regional priority points on the performance of LEED 2009 certified buildings in Turkey, Spain and Italy. Sustainability 2018, 10, 3364. [CrossRef]

89. Choi, J.O.; Bhatla, A.; Stoppel, C.M.; Shane, J.S. LEED credit review system and optimization model for pursuing LEED certification. Sustainability 2015, 7, 13351-13377. [CrossRef]

90. Olakitan Atanda, J. Developing a social sustainability assessment framework. Sustain. Cities Soc. 2019, 44, 237-252. [CrossRef]

91. Stender, M.; Walter, A. The role of social sustainability in building assessment. Build. Res. Inf. 2019, 47, 598-610. [CrossRef]

92. Seinre, E.; Kurnitski, J.; Voll, H. Quantification of environmental and economic impacts for main categoriesof building labeling schemes. Energy Build. 2014, 70, 145-158. [CrossRef]

93. Park, J.; Yoon, J.; Kim, K.-H. Critical review of the material criteria of building sustainability assessment tools. Sustainability 2017, 9, 186. [CrossRef]

94. He, Y.; Kvan, T.; Liu, M.; Li, B. How green building rating systems affect designing green. Build. Environ. 2018, 133, 19-31. [CrossRef]

95. Lee, W.L.; Burnett, J. Benchmarking energy use assessment of HK-BEAM, BREEAM and LEED. Build. Environ. 2008, 43, 1882-1891. [CrossRef]

96. Mahmoud, S.; Zayed, T.; Fahmy, M. Development of sustainability assessment tool for existing buildings. Sustain. Cities Soc. 2019, 44, 99-119. [CrossRef]

97. Castellano, J.; Ribera, A.; Ciurana, J. Integrated system approach to evaluate social, environmental and economic impacts of buildings for users of housings. Energy Build. 2016, 123, 106-118. [CrossRef] 